\title{
Van alle markten thuis
}

Citation for published version (APA):

Herings, P. J. J. (2000). Van alle markten thuis. Datawyse / Universitaire Pers Maastricht. https://doi.org/10.26481/spe.20000616jjh

Document status and date:

Published: 16/06/2000

DOI:

10.26481/spe.20000616jjh

Document Version:

Publisher's PDF, also known as Version of record

\section{Please check the document version of this publication:}

- A submitted manuscript is the version of the article upon submission and before peer-review. There can be important differences between the submitted version and the official published version of record.

People interested in the research are advised to contact the author for the final version of the publication, or visit the DOI to the publisher's website.

- The final author version and the galley proof are versions of the publication after peer review.

- The final published version features the final layout of the paper including the volume, issue and page numbers.

Link to publication

\footnotetext{
General rights rights.

- You may freely distribute the URL identifying the publication in the public portal. please follow below link for the End User Agreement:

www.umlib.nl/taverne-license

Take down policy

If you believe that this document breaches copyright please contact us at:

repository@maastrichtuniversity.nl

providing details and we will investigate your claim.
}

Copyright and moral rights for the publications made accessible in the public portal are retained by the authors and/or other copyright owners and it is a condition of accessing publications that users recognise and abide by the legal requirements associated with these

- Users may download and print one copy of any publication from the public portal for the purpose of private study or research.

- You may not further distribute the material or use it for any profit-making activity or commercial gain

If the publication is distributed under the terms of Article $25 \mathrm{fa}$ of the Dutch Copyright Act, indicated by the "Taverne" license above, 
Van Alle Markten Thuis 


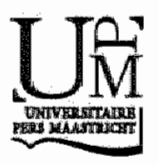

ISBN 9052782784

(C) P. Jean-Jacques Herings, Maastricht 2000 


\title{
Van Alle Markten Thuis
}

\author{
Rede \\ in verkorte vorm uitgesproken \\ bij de aanvaarding van het ambt van \\ hoogleraar in de Algemene Economie \\ in het bijzonder Micro-economie \\ aan de Universiteit Maastricht \\ op vrijdag 16 juni 2000 \\ door \\ P. Jean-Jacques Herings
}


Graag wil ik Suzanne Herings-Smeets, Ronald Peeters, Maarten-Pieter Schinkel en Dolf Talman bedanken voor hun opmerkingen op een eerdere versie van deze inaugurele rede. 
Mijnheer de Rector Magnificus, Zeer gewaardeerde toehoorders,

\section{WORLD ONLINE}

De financiële markten zijn de laatste tijd sterk in beweging. De waarde van aandelen kan van de ene op de andere dag in hoge mate veranderen, soms zonder dat daar ogenschijnlijk duidelijk aanwijsbare redenen voor zijn. In het bijzonder nieuw op de effectenbeurs geïntroduceerde bedrijven hebben vaak te maken met grote koersschommelingen, te meer indien ze actief zijn in de informatie- en communicatietechnologie sectoren van de zogeheten nieuwe economie.

De internetaanbieder World Online is een voorbeeld van een onderneming in de informatietechnologie sector. Op vrijdag 17 maart $2000 \mathrm{kreeg}$ World Online voor het eerst een notering aan de Amsterdamse effectenbeurs. De verwachtingen rondom dit bedrijf waren hoog gespannen. Bij de uitgiftekoers van 43 euro werden er maar liefst 21 keer meer aandelen gevraagd dan de ruim 67,5 miljoen die beschikbaar waren. In de grijze handel werd 115 euro voor het aandeel geboden.

Beleggers die verwacht hadden snel een fikse winst te kunnen boeken, kwamen echter van een koude kermis thuis. Kort na de opening van de handel deden veel beleggers het aandeel onmiddellijk in de verkoop. De slotkoers van de eerste beursdag was 43,20 euro, slechts $0,5 \%$ boven de introductiekoers. De slotkoers van de tweede beursdag was 37,40 euro, een daling van $13,4 \%$ in één dag tijd. Mogelijke verklaringen voor deze koersdaling varieerden van teleurstelling over het feit dat World Online er niet in geslaagd was het amusementsconcern Endemol over te nemen, tot de hypothese dat veel particulieren meer aandelen toegewezen hadden gekregen dan verwacht, en deze in de verkoop deden. De slotkoers van de derde beursdag was 29,95 euro, een daling met $19,9 \%$ ten opzichte van de vorige beursdag. En hiermee was de bodem van de koers nog lang niet bereikt.

U zult mogelijk concluderen dat de introductiekoers wan het aandeel World Online te hoog is geweest. Dat lijkt echter in tegenspraak met het gegeven dat de emissie van het aandeel 21 keer overtekend was. Toch zal de vraag op de eerste beursdag in werkelijkheid ongeveer gelijk geweest zijn aan het aanbod, getuige de slotkoers die slechts een fractie hoger was dan de openingskoers. Bij het gegeven dat de vraag het aanbod 
met een factor 21 overtrof, dienen een aantal kanttekeningen geplaatst te worden. Veel vragers zullen op een groter aantal aandelen ingetekend hebben dan ze in werkelijkheid wilden hebben, omdat ze verwachtten dat het toegewezen aantal aandelen aanzienlijk lager zou liggen dan het gevraagde aantal. Inderdaad kregen abonnees van World Online slechts 17,5 procent wan het ingetekende aantal aandelen, en niet-abonnees, die dan ook nog klant moesten zijn van ABN Amro of Rabobank, slechts 6 procent. Bovendien waren veel vragers tegelijkertijd aanbileders, omdat hun strategie bestond uit het onmiddellijk verkopen van de hen toegewezen aandelen.

Op de tweede beursdag waren er meer beleggers die het aandeel wilden verkopen tegen de slotkoers van de vorige beursdag; dan beleggers die het voor die koers wilden aankopen. De aandelenkoers daalt dan totdat de vraag gelijk is aan het aanbod, en een zogeheten evenwichtsprijs tot stand komt. Op de tweede beursdag was hiervoor een koersdaling van $13,4 \%$ noodzakelijk. Op de derde beursdag herhaalde dit fenomeen zich, en was er zelfs sprake van een koersdaling van 19,9\%. Op deze wijze komt er iedere dag een evenwichtsprijs van het aandeel World Online tot stand, waarbij evenwichtsprijzen van dag tot dag, en vaak ook binnen een dag, flinke schommelingen kunnen vertonen. De aandelenmarkt is in staat grote verschuivingen in vraag- en aanbodverhoudingen soepel op te vangen.

Het bowenstaande verhaal geeft een simpele beschrijving van het overeenkomen van vraag en aambod door middel van een koersaanpassing. Deze beschrijving roept echter minstens evenveel vragen op als dat ze beantwoordt.

Leidt een koersdaling van een aandeel altijd tot minder aanbod en meer vraag? Het antwoord luidt zonder enige twijfel ontkennend. Een koersdalling kan een signaal zijn dat het slecht met een bedrijf gaat, hetgeen nog meer beleggers aanzet tot verkoop en minder beleggers verleidt tot aankoop. In dit geval verschaft de koers van het aandeel nieuwe informatie aan beleggers, hetgeen een ander aan- en verkoopgedrag tot gevolg heeft. Verder leidt een koersdaling van een aandeel tot een daling van het vermogen wan de bezitter ervan. Deze zou daarom kunnen besluiten minder van dit aandeel in zijn beleggingsportefeuille op te nemen, oftewel aandelen aan te bieden.

Als een koersdaling van een aandeel ook tot meer aanbod en minder vraag kan leiden, bestaat er dan wel altijd een koers waarbij vraag gelijk is aan aanbod? En is een daling van de koers dan wel de juiste manier om een evenwicht van vraag en aanbod te bereiken? En is er reden om 
aan te nemen dat er slechts één koers kan zijn waarbij vraag gelijk is aan aanbod? Op basis van de praktijk lijkt het antwoord op alle vragen bevestigend te zijn. Maar kunnen we ook beargumenteren waarom dat het geval is?

Het moge duidelijk zijn dat veel beleggers in World Online flink wat gell verloren hebben. Het handelen op de effectenbeurs kan bijzonder risicovol zijn. De vraag dient zich daarom aan of het bestaan van een effectenbeurs wel bijdraagt aan de welvaart van een land, of dat eèn owerheid er goed aan zou kunnen doen om handel in aandelen te verbieden.

Een cruciale vraag voor iedere belegger is de volgende. Is het mogelijk om het verwachte rendement alsmede het risico van beleggen in aandelen te voorspellen? Het rendement op het aandeel World Online bedroeg respectievelijk $0,5 \%,-13,3 \%$ en $-19,9 \%$ per dag gedurende de eerste drie beursdagen. Om dit rendement te kunnen bepalen, volstaat het om de koersen van het aandeel World Online te weten. Om het rendement van een aandeel te voorspellen, moeten we dus de toekomstige evenwichtsprijzen van dat aandeel voorspellen.

Daar deze vragen niet zo eenvoudig zijn, stel ik de beantwoording ervan nog even uit.

\section{WERKLOOSHEID}

Op de aandelenbeurs komt op vrijwel ieder moment in de tijd een evenwichtsprijs tot stand met gelijkheid van vraag en aanbod van aandelen. Het is echter niet zo moeilijk voorbeelden van markten te geven, waarop vraag en aanbod langdurig van elkaar verschillen. Een voorbeeld is de arbeidsmarkt. Het gemiddelde werkloosheidspercentage in de Europese Unie ligt al sinds jaren om en nabij de $10 \%$ van de beroepsbevolking. Werkloosheid is eigenlijk niets anders dan het verschijnsel dat het aanbod van arbeid groter is dan de vraag ernaar, een aanbodoverschot van arbeid dus. Wat we aanduiden met loon of salaris is hetzelfde als de prijs van arbeid. In tegenstelling tot de prijs van aandelen, vindt er kennelijk geen aanpassing van de prijs van arbeid plaats zodanig dat gelijkheid van vraag en aambod van arbeid resulteert. Bovendien kan cen situatie met werkloosheid zich gedurende lange tijd woordoen.

Ofschoon het gemiddelde werkloosheidspercentage in de Europese Unie om en nabij de $10 \%$ ligt, lijkt de Nederlandse situatie een stuk rooskleuriger. Zo meldde het Centraal Bureau voor de Statistiek (CBS) dat in het eerste kwartaal van $2000 \mathrm{er}$ in Nederland 198.000 werklozen waren. Ofschoon dat nog steeds betekent dat bijna $3 \%$ van het Neder- 
lands arbeidspotentieel onbenut blift, komt $3 \%$ aardig overeen met een werkloosheidspercentage dat economen als onvermijdelijk zien en aanduiden met frictiewerkloosheid. Dit is werkloosheid die ontstaat ondat er tijd nodig is vraag en anbod van arbeid bij elkaar te brengen. Werkzoekenden hebben bepaalde voorkeuren voor het soort werk dat ze willen doen, en kwalificaties die bepalen welk werk ze kummen doen. Vacatures die worden aangeboden hebben bepaalde karakteristieken en stellen een aantal vereisten. Het kost daarom tijd om vraag en aanbod van arbeid goed op elkaar aan te laten sluiten, hetgeen leidt tot frictiewerkloosheid. Een kenmerk van frictiewerkloosheid is dat deze van relatief korte duur is. Veel van de Nederlandse werklozen zijn echter langdurig werkloos. Er zijn daarom gegronde redenen tot twijfel of de Nederlandse werkloosheid frictiewerkloosheid is.

Een andere kanttekening is dat het gevaarlijk is om over arbeid in het algemeen te spreken, zonder een onderscheid te maken naar verschillende typen arbeid. Voor sommige typen van arbeid is er geen aanbodoverschot, maar een vraagoverschot. Zo meldt de arbeidsvoorziening dat er in 1998 in totaal 329.298 geregistreerde vacatures waren, waarvan 34.752 voor verkopers, 24.251 voor administratief medewerkers, 20.719 woor productiemedewerkers, 18.192 woor leerkrachten en docenten, en 13.753 voor schoonmakers. Het is dus van belang onderscheid te maken tussen de verschillende typen arbeid.

Waar op de aandelenmarkt voortdurend een evenwicht tot stand lijkt te komen met gelijkheid van vraag en aanbod van aandelen, is de arbeidsmarkt vaak uit evenwicht, waarbij het aanbod van arbeid meestal groter is dan de vraag ernaar. Een belangrijk verschil tussen deze twee typen markten is dat extra vraag of extra aanbod voor een aandeel vrijwel onmiddellijk leidt tot een aanpassing van de prijs van het aandeel, de aandelenkoers. Op arbeidsmarkten ligt dat meestal anders. Zo heeft een extra aanbod van hooggekwalificeerde micro-economen geen direct gevolg voor het salaris van een hoogleraar micro-economie. Lonen zijn, zeker op korte termijn, en waak ook op langere termijn, inflexibel, in het bijzonder in neerwaartse richting.

Een belangrijke vraag betreft de verklaring waarom lonen zich niet altijd aanpassen aan vraag- en aanbodverhoudingen. Dit is een vraagstuk dat in de economische literatuur niet onbesproken is gebleven. Een erg voor de hand liggend antwoord wijst op het bestaan van minimumlonen. Aangezien er slechts weinig werknemers met een minimumloon zijn, is dit maar een gedeeltelijk antwoord. Bovendien lokt het de vraag uit waarom er minimumlonen zijn, een vraag waarop ik later nog terug zal 
komen. Een andere verklaring bestaat wit de macht die partijen zoals vakbonden of werkgeversverenigingen hebben bij loononderhandelingen. Door deze macht te gebruiken kunnen er lonen tot stand komen die afwijken van lonen waarbij vraag gelijk is aan aanbod. In Nederland is er bovendien sprake wan het algemeen verbindend verklaren van collectieve arbeidsovereenkomsten, hetgeen deze verklaring nog belangrijker maakt. Nog een andere verklaring is dat het voor een afzonderlijk bedrijf aantrekkelijk kan zijn lonen te betalen waarbij er meer aanbod dan vraag van arbeid is. Dit is het geval als het betalen van een hoger loon leidt tot een grotere productiviteit wan werknemers, bijvoorbeeld omdat er dan minder verloop is van werknemers, het bedrijf beter gekwalificeerde werknemers aan kan trekken, of omdat werknemers dan meer bereid zijn zich voor het bedrijf in te spannen.

Het argument dat het gebrek aan Hexibiliteit van lonen een belangrijke verklaring is voor het bestaan van werkloosheid, suggereert dat er loonniveaus bestaan waarbij er wel gelijkheid is van vraag en aanbod van arbeid, en er dus geen werkloosheid is. Een dergelijk loonniveau heet een evenwichtsloon. Is er inderdaad een evenwichtsloon? En is er slechts één zo'n evenwichtsloon, of zouden er meerdere evenwichtslonen kunnen zijn? En als een evenwichtsloon bestaat en lonen flexibel zijn, zullen vraag- en aanbodwerhoudingen op de arbeidsmarkt er dan voor zorgen dat het evenwichtsloon, waarbij er geen werkloosheid is, tot stand komt?

De redenering waarom een evenwichtsloon tot stand komt, kan als volgt geillustreerd worden aan de hand van het eerder genoemde voorbeeld met de hoogleraar micro-economie. Als het aanbod van hoogleraren micro-economie hoger is dan de vraag ernaar, dan kunnen de universiteiten hun salaris verlagen. Sommige micro-economen zullen hun geluk dan in andere professies beproeven. Het aanbod van micro-economen daalt. Als het salaris van een hoogleraar micro-economie lager wordt, is het goedkoper voor universiteiten om meer hoogleraren micro-economie in dienst te nemen. De vraag naar micro-economen stijgt. De salarisdaling gaat net zo lang door totdat vraag en aanbod van hoogleraren micro-economie aan elkaar gelijk zijn. Een omgekeerde redenering gaat op in het geval de vraag naar micro-economen het aanbod overtreft.

De redenering gaat ervan uit dat het aanbod van micro-economen afneemt naarmate hun salaris daalt. In het voorbeeld over World Online heb ik reeds aangegeven dat dit voor aandelen niet zo hoeft te zijn. Maar zelfs als dat voor arbeid wel zo is, is het nog niet duidelijk of het bovenbeschreven mechanisme inderdaad tot evenwicht van vraag en aan- 
bod op alle arbeidsmarkten tegelijkertijd leidt. De micro-economen die hun geluk op een andere arbeidsmarkt gaan beproeven, zorgen voor een extra aanbod aldaar. Op die markten ontstaan dan ook salarisdalingen, die de markt voor hoogleraren micro-economie weer uit evenwicht kunnen brengen. Kan het gebeuren dat de wisselwerking tussen markten ervoor zorgt dat ze nooit tegelijkertijd in evenwicht geraken?

Als een volledig vrije loonvorming de oplossing is voor werkloosheid, doet een overheid er dan niet verstandig aan om een dergelijke loonvorming te bewerkstelligen? Of doen de sterk fluctuerende salarissen die dan te verwachten zijn, alle positieve effecten weer teniet? En tenslotte, is het mogelijk om de mate van werkloosheid die resulteert als lonen afwijken van hun evenwichtswaarden te voorspellen?

De voorbeelden omtrent het aandeel World Online en de Nederlandse werkloosheid, ofschoon twee ogenschijnlijk totaal verschillende onderwerpen, leiden tot dezelfde vijf fundamentele vragen. Bestaan er evenwichtsprijzen waarbij op alle markten vraag gelijk is aan aanbod? Zijn evenwichtsprijzen uniek bepaald? Komen evenwichtsprijzen vanzelf tot stand in een vrije markteconomie? Zijn evenwichtsprijzen gewenst vanuit een sociaal oogpunt? Kunnen we voorspellen welke evenwichtsprijzen tot stand komen?

\section{Het Algemeen Evenwichtsmodel}

Een groot aantal concepten zijn tot nu toe in mijn rede nogal losjes gedefinieerd. Een evenwichtige prijs is omschreven als een prijs waarbij vraag en aanbod op een markt aan elkaar gelijk zijn. Maar, wat betekenen de woorden "prijs," "markt," "vraag" en "aanbod" precies?

Een ander probleem is dat het in het algemeen onmogelijk is om één bepaald goed of één bepaald aandeel los te zien van alle andere goederen en alle andere aandelen. Bijvoorbeeld, het is onmogelijk om een specifiek aandeel als World Online los te zien van andere aandelen van internetaanbieders, of van andere aandelen in het algemeen, of van andere soorten van financiële vermogenstitels zoals obligaties, of zelfs van andere soorten van markten zoals de arbeidsmarkt. Is bijvoorbeeld het werkloosheidspercentage flink gedaald, dan wijst dat op een krappere arbeidsmarkt. Volgens de standaardredenering verwachten beleggers dan flinke looneisen van werknemers, leidend tot prijsstijgingen van producten, ofwel inflatie, hetgeen leidt tot hogere rentestanden, minder vraag naar aandelen en een lagere aandelenkoers. Voor een beter begrip van het koersverloop van een aandeel is dus ook inzicht in andere mark- 
ten, waaronder de arbeidsmarkt, wereist. Andersom zijn de gebeurtenissen op de aandelenmarkten van invloed op de arbeidsmarkten. Volgens een andere standaardredenering leiden stijgende aandelenkoersen tot stijgende vermogens van huishoudens, die daardoor meer vraag uitoefenen naar producten, hetgeen werkloosheid doet verminderen.

Ik heb beargumenteerd dat voor een goed begrip van economische fenomenen, het samenspel tussen markten van belang is. Bovendien heb ik aangegeven dat men niet kan volstaan met globale termen als arbeidsmarkt en aandelenmarkt. Het is essentieel om arbeidsmarkten te splitsen in de arbeidsmarkt voor verkopers, administratief medewerkers, productiemedewerkers, leerkrachten, enzovoorts. Als u nu denkt dat er dan well een heel ingewilkkeld geheel ontstaat, dan hebt u gelijk. Het is hier dat de introductie van de wiskundige gereedschapskist onontbeerlijk gebleken is. Modellen die het economische systeem als geheel beschrijven staan bekend als algemeen evenwichtsmodellen. Een algemeen evenwichtsmodel maakt het mogelijk een antwoord te geven op de vijf eerder geformuleerde fundamentele vragen.

De moderne algemeen evenwichtstheorie maakt gebruik van de axiomatische methode. In de axiomatische methode worden alle basisonderdelen van de economie, de zogenaamde primitieve concepten, nauwkeurig gedefinieerd en omschreven. Voorbeelden van primitieve concepten zijn huishoudens, bedrijven en goederen. Vervolgens maakt men aannamen op deze primitieve concepten, bijvoorbeeld dat huishoudens onverzadigbare behoeften hebben en dat bedrijven trachten hun winst te maximaliseren. Deze aannamen zijn vergelijkbaar met wiskundige axioma's. De primitieve concepten zijn exogeen gegeven variabelen, die niet nader verklaard worden. Dit in tegenstelling tot de zogenaamde endogene variabelen die verklaard worden door de theorie. Voorbeelden van endogene variabelen zijn aandelenkoersen en werkloosheidspercentages. Het gebruik maken van de axiomatische methode leidt tot diepe inzichten, voorkomt onjuiste redeneringen en verbetert de communicatie binnen de economische wetenschap.

Een economie bestaat uit een beschrijving van alle primitieve concepten. Een toestand van de economie bestaat uit een beschrijving van alle endogene variabelen. De algemeen evenwichtstheorie geeft aan wanneer een toestand een evenwichtstoestand is, ook wel eenvoudigweg even wicht genoemd. In het algemeen is een evenwichtstoestand cen zodanige toestand van de economie dat, nadat deze bereikt is, er geen verandering in plaats zal vinden. Ik zal nu in het kort het basismodel van de algemeen evenwichtstheorie, het Arrow-Debreu-McKenzie (ADM) model 


\section{uiteenzetten.}

In het ADM-model kunnen een aantal primitieve concepten onderscheiden worden. Ten eerste zijn er de agenten die in het economisch systeem een rol spelen, en wel huishoudens en bedrijven. Ten tweede zijn er goederen die de huishoudens en bedrijven verhandelen. Ik gebruik hier het woord goederen in algemene zin, dat wil zeggen dat het ook betrekking heeft op diensten. Voorbeelden van goederen zijn olie, kapitaalgoederen, kappersdiensten en futures voor suiker. In principe zijn twee goederen verschillend als hun fysieke kenmerken verschillend zijn, denk aan olie versus kappersdiensten, of als de locatie waarop goederen beschikbaar komen verschillend is, een kappersdienst in Maastricht is een ander goed dan een kappersdienst in Sittard, of als het tijdstip waarop goederen beschikbaar komen verschillend is. Dit laatste speelt een grote rol op de financièle markten. Een future voor suiker is een contract dat de leverantie van een bepaalde hoeveelheid suiker op een nader bepaald toekomstig tijdstip specificeert. Twee futures voor suiker met verschillende toekomstige tijdstippen van leverantie zijn twee verschillende goederen. De hoeveelheid van leder goed wordt vastgelegd met een bepaalde meeteenheid; liters, stuks, kilo's, uren, enzovoorts.

Ieder huishouden en ieder bedrijf wordt gekenschetst door zijn verzameling mogelijk te ondernemen acties en door zijn doelstellingen. Ieder huishouden en leder bedrijf tracht een optimale actie te kiezen, dat wil zeggen een actie die zo goed mogelijk tegemoet komt aan zijn doelstellingen.

De actie van een huishouden bestaat uit de keuze van een consumptiebundel, een lijst met aangeboden en gevraagde hoeveelheden van alle beschikbare goederen. De consumptiebundel van mijn eigen huishouden bestaat momenteel onder andere uit het aanbieden van 36 uur per week micro-economisch onderwijs en onderzoek in Mastricht en 16 uur per week administratieve arbeid in Heerlen, en de vraag naar een groot aantal goederen, waaronder treintransport, bloemen en babyvoeding. De verzameling van alle mogelijk te kiezen consumptiebundels van een huishouden heet een consumptieverzameling.

De actie van een bedrijf bestaat uit de keuze van een productiebundel binnen een exogeen gegeven verzameling wan productiemogelijkheden. Deze verzameling geeft alle technologisch mogelijke productiehoeveelhe-

'Het model heeft zijn moderne yorm verkregen dankzij het werk van Arrow (1951), Debreu (1952), Arrow en Debreu (1954) en McKenzie (1954, 1955). Voor een in helderheid niet te overtreffen uiteenzetting van dit model is Debreu (1959) de meest geschikte referentie. Dit boek is van grote invloed geweest op mijn eigen werk. 
den van een bedrijf weer. In het algemeen heeft een bedrijf een breed. palet van mogelikheden met betrekking tot de inzet van grondstoffen, arbeidskrachten en kapitaalgoederen. Een productiebundel is daarom, net zo als een consumptiebundel, een lijst met aangeboden en gevraagde hoeveelheden van goederen.

De doelstellingen van een huishouden worden beschreven door een voorkeursrelatie. Een voorkeursrelatie geeft voor elk tweetal consumptiebundels aan welke de voorkeur heeft. Ieder huishouden heeft in principe een andere voorkeursrelatie. Ieder huishouden kiest een consumptiebundel op zodanige wijze dat er geen andere consumptiebundel bestaat die de voorkeur heeft. De doelstelling van een bedrijf bestaat uit het kiezen van een productiebundel die een zo'n hoog mogelijke winst oplevert.

De winst van een productiebundel hangt af van de waarde van de goederen die bij het productieproces gebruikt worden, de kosten van het bedrijf, en de waarde van de goederen die het productieproces oplevert, de opbrengsten van het bedrijf. Om de waarde van een productiebundel te kunnen bepalen, is het van belang de prijzen van alle goederen te kennen. De prijs van een goed, uitgedrukt in een bepaalde rekeneenheid, specificeert wat de waarde is van één eenheid van dat goed. Prijzen zijn niet alleen van belang om de winst van een bedrijf te kunnen bepalen. Prijzen beperken ook de mogelijkheden van een huishouden om consumptiebundels aan te schaffen.

Een huishouden verkrijgt inkomen door middel van het aanbod van goederen, in de meeste gevallen arbeid, en eventueel door een aandeel in de winsten van bedrijven. Een algemeen evenwichtsmodel start de beschrijving van het economisch systeem op een bepaald moment in de tijd. Alle goederen die huishoudens op dat moment in bezit hebben, alsmede de aandelen die ze op dat moment van de verschillende bedrijven bezitten, worden aangeduid met het initieel bezit van een huishouden. Eén van de belangrijkste onderdelen van het initieel bezit van de meeste huishoudens is het aanwezige menselijk kapitaal, dat bepaalt welke soorten arbeid het huishouden kan aanbieden. De prijzen van goederen en het injtieel bezit van goederen bepalen samen het inkomen van een huishouden. De budgetverzameling van een huishouden bestaat uit alle consumptiebundels die in de consumptieverzameling zitten en die in waarde het inkomen van het huishouden niet overschrijden. Een huishouden doet bij gegeven prijzen een optimale keuze uit alle consumptiebundels in de budgetverzameling.

De handel van goederen vindt plaats op markten. Voor ieder goed 
is er een markt, waar dat goed tegen zijn prijs verhandeld wordt. Het begrip markt is hier in de ruimst mogelijke zin van het woord gebruikt. De markt van een goed brengt vraag en aambod wan dat goed samen. De vraag en het aanbod van elk goed volgt uit de optimaal gekozen consumptie- en productiebundels. Het vraagoverschot in de economie resulteert door voor ieder goed de totale vraag minus het totale aanbod te nemen. Als prijzen door de overheid gekozen worden, hetgeen bijvoorbeeld veelvuldig het geval was in de centraal geleide economieën van Oost-Europa en de voormalige Sovjetunie, maar waarin ook de Europese Unie zich niet onbetuigd laat, zullen in het algemeen niet verwaarloosbare vraagoverschotten tot stand komen. Voor sommige goederen zal er meer vraag zijn dan aanbod, dat wil zeggen een positief vraagoverschot, en voor andere goederen meer aanbod dan vraag, een negatief vraagoverschot ofwel een aanbodoverschot. In het algemeen zal er een positief vraagoverschot zijn wanneer de overheid de prijs van een goed te laag vastgesteld heeft, en een aanbodoverschot indien de overheid een te hoge prijs voor een goed gekozen heeft. De relatie die aan ieder stelsel van prijzen de resulterende vraagoverschotten toekent, heet de vraagoverschotfunctie.

Een toestand van de economie bestaat uit de prijzen van alle goederen. Gegeven de prijzen van goederen bepalen de huishoudens hun optimale consumptiebundels en de bedrijven hun optimale productiebundels. De prijzen van de goederen leggen alle interessante grootheden in een economie volledig vast, zoals lonen, het nationaal product, de inkomensverdeling, importen en exporten, enzovoorts. Een algemeen evenwichtsmodel bepaalt welke toestand, dus wellk stelsel van prijzen, in de economie tot stand komt. Hieruit kunnen alle van belang zijnde economische cijfers worden afgeleid.

Het ADM-model is bedoeld als cen beschrijving van een vrije markteconomie. In tegenstelling tot een centraal geleide economie, waarin de overheid prijzen van goederen bepaalt, komen prijzen tot stand op basis van vraag- en aanbodverhoudingen. Is er naar een goed meer vraag dan aanbod, dan zullen sommige vragers teleurgesteld zonder het goed thuiskomen. Zij zullen er de voorkeur aan geven meer voor dat goed te betalen dan de huidige prijs. Evenzo zullen aanbieders van dat goed beseffen dat het mogelijk is hun gehele aanbod te slijten voor een hogere prijs. Kortom, de prijs van het goed zal stijgen. Een soortgelijke redenering levert op dat de prijs van een goed zal dalen als er meer aanbod is dan vraag. Het is alleen als vraag en aanbod van alle goederen aan elkaar gelijk zijn, dus het vraagoverschot voor alle goederen nul is, dat prijzen 
van goederen niet langer veranderen. Dit noemen we een evenwichtstoestand, of ook wel een evenwicht. Een evenwicht in het ADM-model is dus een stelsel van prijzen waarbij voor alle goederen de vraag gelijk is aan het aanbod. Het model gaat ervan uit dat een vrije markteconomie op elk moment in de tijd in evenwicht is.

\section{GESCHIEDENIS VAN HET ALGEMEEN EVENWICHTSMOdEL.}

Het werk van Adam Smith (1776), "An Inquiry into the Nature and Causes of the Wealth of Nations," kan men beschouwen als de eerste poging or een theorie van het economisch systeem als geheel op te stellen. Centraal in het werk van Smith staat de gedachte dat het prijsmechanisme in een vrije markteconomie leidt tot een optimale coördinatie van consumptie- en productiebeslissingen. Ofschoon er zeer veel huishoudens en bedrijven in de economie zijn, mogelijk met conflicterende belangen, en ofschoon ieder huishouden volgens zijn eigen voorkeursrelatie handelt en ieder bedrijf zijn eigen winst tracht te maximaliseren, komt er een evenwicht in de economie tot stand dat optimaal is voor alle betrokkenen. De evenwichtsprijzen coördineren de consumptie- en productiebeslissingen van huishoudens en bedrijven als een onzichtbare hand.

Het eerste volledig gespecificeerde algemeen evenwichtsmodel, het eerder gegeven concept van evenwicht, en een eerste analyse van de vraag hoe een economie in een dergelijk evenwicht terechtkomt, werd gegeven door de Fransman Léon Walras. ${ }^{2}$ Het evenwicht in het ADM-model heet ook wel een Walrasiaans evenwicht.

Walras had ook al oog voor het door mij eerder beschreven proces van prijsaanpassing indien er van nul afwijkende vraagoverschotten zijn. Een wiskundige formalisering van dit proces is gegeven in Samuelson (1941), en staat bekend als het Walrasiaanse tatonnement proces. Volgens dit prijsaanpassingsproces stijgen prijzen bij positieve vraagoverschotten en dalen prijzen bij negatieve vraagoverschotten, totdat alle markten in evenwicht zijn. Zolang dit niet het geval is, vindt er geen handel plaats.

Het Walrasiaanse tatonnement proces is een nogal mechanisch aandoend proces, dat ver verwijderd lijkt te zijn wan de eerder gegeven beschrijwing van biedprocessen van huishoudens en bedrijven in het geval dat vraagoverschotten ongelijk aan nul zijn. In het ADM-model nemen

\footnotetext{
2 Walias (1874) beschrijt een uitputtend model wan een markteconornie, en in tegenstelling tot wat vaak gedacht wordt, met inbegrip van kapitaalgoederen en geld.
} 
alle huishoudens en bedrijven de prijzen als gegeven aan. Er is niemand die de prijzen aanpast. Om dit probleem op te lossen, wordt vaak de Walrasiaanse veilingmeester als metafoor voor prijsaanpassing door individuele huishoudens en bedrijven naar voren geschoven. Problematisch is ook dat er geen handel plaatswindt totdat alle markten in evenwicht zijn. Kortom, bestudering van het Walrasiaanse tatonnement proces is slechts een eerste noodzakelijke stap in de studie van prijsaanpassingsprocessen in vrije markteconomieën, en zeker niet het eindpunt.

Veel economen hebben blijk gegeven van een schier grenzeloze bewondering voor Walras, waaronder de vermaarde econoom Schumpeter die vond:

As far as pure theory is concerned, Walras is in my opinion the greatest of all economists. His system of economic equilibrium, uniting as it does the quality of "revolutionary" creativeness with the quality of classical synthesis, is the onily work by an economist that will stand comparison with the achievements of theoretical physics. ${ }^{3}$

De kenners van het Frans onder u denken wellicht dat ik Walras uit dien te spreken als "Walra." Niets is echter minder waar, de uitspraak is Walras. De naam Walras is sowieso niet erg Frans, gezien bijwoorbeeld de eerste letter, "W." De naam Walras is een Franse verbastering van het Nederlandse Walravens. ${ }^{4}$ En inderdaad is de overgrootvader van Léon Walras een Nederlander, Andreas Walravens. Gezien het feit dat ik deze rede in Maastricht uitspreek, misstaat het niet te vermelden dat Andreas Walravens uit Limburg kwam, geboren in 1724 in Arcen.

Het werk van Edgeworth (1881) en Pareto (1909) dient ook genoemd te worden. Beide auteurs analyseerden het vraagstuk of consumptie en productie in een economie op optimale wijze geschieden, hetgeen heeft geleid tot het criterium van Pareto-efficientie als maatstaf voor optimaliteit. Consumptie en productie geschieden op Pareto-efficiënte wijze als het niet mogelijk is om andere consumptie- en productiebundels te kiezen zodat alle huishoudens minstens even goed af zijn en tenminste één huishouden beter. Pareto-efficiëntie geeft ons een handvat om de sociale wenselijkheid van economische systemen te beoordelen.

ZZie Van Daal en Jolink (1993). 


\section{KRITIEK OP HET ALGEMEEN EVENWICHTSMODEL}

Het algemeen evenwichtsmodel is zowel in het heden als in het verleden niet gevrijwaard gebleven van kritiek. Fen groot deel van die kritiek komt overeen met die van een student in een door de econoom Weintraub geschreven stuk in vier bedrijven, zie Weintraub (1985), blz. 12:

It is as though the puzzle of general equilibrium theory took on a mathematical life of its own as it became the plaything of some very smart mathematical economists who worked and worked and fimally constructed a beautiful theory. But by the time they had finished, the construction was no longer relevant to the economic world.

Ofschoon ik mij uiteraard gevleid voel door de opmerking dat de algemeen evenwichtstheorie beoefend wordt door zeer slimme mensen, en dat de algemeen evenwichtstheorie een prachtige theorie is, getuigt de opmerking van deze student niet van veel intelligentie. De student verwart abstractie en irrelevantie. Het is deze verwarring die in het verleden meerdere malen in verscheidene wetenschappelijke disciplines vooruitgang heeft doen stagneren. Ik sluit me dan ook graag aan bij Russell (1931), blz. 85:

Many people have a passionate hatred of abstraction, chiefly, I think, because of its intellectual difficulty; but as they do not wish to give this reason, they invent all sorts of others that sound grand. They say that all reality is concrete, and that in making abstractions we are leaving out the essential. They say that all abstraction is falsification, and that as soon as you have left out any aspect of something actual you have exposed yourself to the risk of fallacy in arguing from its remaining aspects alone. Those who argue in this way are, in fact, concermed with matters quite other than those that concern science.

Een wat beter doordachte kritiek is dat de algemeen evenwichtstheorie op een dood spoor zit, omdat ze niet heeft geleid tot falsificeerbare hypothesen. Blaug (1980), blz. 192, verwoordt dit als volgt:

... without throwing away the general equilibriurn construction, what may be doubted is the notion that it provides 
a useful starting point from which to approach a substantive explanation of the workings of an economic system. Its leading characteristic has been the endless formalization of purely logical problerns without the slightest regard for the production of falsifiable theorems, which, we insist, remains the fundamental task of economics.

Blaug vergist zich, en wel op twee fronten. Ten eerste is het feitelijk onjuist dat de algemeen evenwichtstheorie niet de minste aandacht heeft gehad voor het produceren van falsificeerbare hypothesen. Wiskundig economen hebben veel aandacht geschonken aan het rraagstuk of de algemeen evenwichtstheorie het mogelijk maakt falsificeerbare hypothesen woort te brengen, hetgeen geresulteerd heeft in het SonnenscheinMantel-Debreu (SMD) theorema ${ }^{5}$ Het SMD-theorema beweert dat het ADM-model geen restricties oplegt aan vraagoverschotfuncties. Dat will zeggen, geen restricties buiten de wet van Walras, homogeniteit van de graad nul, continuitteit, en het exploderen van vraagoverschotten als prijzen naar nul gaan.

Het SMD-theorema kwam als een grote schok voor de algemeen evenwichtstheorie omdat het laat zien dat deze theorie inderdaad veel minder beperkingen oplegt, en dus falsificatie veel moeilijker maakt, dan altijd gedacht werd. Het theorema is helaas vaak ten onrechte geïnterpreteerd als een bewijs dat de algemeen evenwichtstheorie geen falsificeerbare stellingen kan voortbrengen. Dat deze interpretatie onjuist is, is overtuigend aangetoond door het artikel van Brown en Matzkin (1996). Dit artikel leidt door het ADM-model voortgebrachte falsificeerbare hypothesen af, in de vorm van restricties op met het ADM-model consistente combinaties van initieel bezit en evenwichtsprijzen.

Ten tweede kan men, uitgaande van "sophisticated methodological falsificationism," een theorie van de wetenschapsfilosoof Lakatos (1970), beargumenteren dat de algemeen evenwichtstheorie niet beoordeeld moet worden op haar vermogen falsificeerbare hypothesen te genereren. Lakatos vindt dat de taak van de wetenschapper niet zozeer is om te zoeken naar bevestiging, maar naar falsificatie. Hij sluit daarmee aan bij de wetenschapsfilosoof Popper $(1959,1972)$. Lakatos onderscheidt zich van Popper in zijn opvatting dat hetgeen gefalsificeerd dient te worden, niet zozeer een individuele theorie is, maar een wetenschappelijk onderzoeksprogramma.

${ }^{5}$ Het Sommenschein-Mantel-Debreu theorema is een voortvloeisel van het werk van Sonnenschein $(1972,1973)$, Mantel (1974) en Debreu (1974). 
Een wetenschappelijk onderzoeksprogramma bestaat uit een viertal elementen, de "hard core," de "positive heuristic," de "negative heuristic," en de "protective belt." De hard core bestaat uit een aantal veronderstellingen die door de aanhangers van een wetenschappelijk onderzoeksprogramma voor waar worden aangenomen. De positive heuristic bestaat uit regels die aangeven hoe het mogelijk is om met behulp van de hard core verwerpbare theorieën te produceren. De negative heuristic bestaat uit beweringen die er toe dienen de hard core te beschermen tegen kritiek. De protective belt bevat een groot aantal individuele theorieën die met behulp van de hard core en de regels van de positive heuristic opgesteld zijn, en waarvoor falsificatie mogelijk is.

Er valt veel voor te zeggen om niet de algemeen evenwichtstheorie als een wetenschappelijk onderzoeksprogramma te definiëren, maar, aansluitend bij de opvatting van Weintraub (1985), te spreken van een neo-Walrasiaans onderzoeksprogramma. De hard core van dat onderzoeksprogramma gaat uit van de volgende veronderstellingen ${ }^{6}$

1. Er bestaan economische agenten.

2. Agenten hebben voorkeuren over uitkomsten.

3. Agenten optimaliseren op onafhankelijke wijze onder nevenvoorwaarden.

4. Keuzes worden gemaakt op samenhangende markten.

5. Agenten beschikken over alle relevante kennis.

6. Waargenomen economische uitkomsten zijn gecoördineerd, zodat ze besproken dienen te worden met een verwijzing naar evenwichtstoestanden.

Weintraub beschouwt de algemeen evenwichtstheorie als de hard core van het neo-Walrasiaanse onderzoeksprogramma. Ik ben het hiermee eens, met de kanttekening dat de algemeen evenwichtstheorie breder is dan de hard core van het neo-Walrasiaanse onderzoeksprogramma. De door mij aanstonds te bespreken algemeen evenwichtstheorie met prijsstarheden en coördinatieproblemen kan dienen als de hard core van een neo-Keynesiaans onderzoeksprogramma.

De positive heuristic van het neo-Walrasiaanse programma bestaat uit het construeren van theorieën waarin economische agenten optimaliseren, en waarin voorspellingen worden gemaakt over veranderingen in evenwichtstoestanden. De negative heuristic bestaat uit het vermijden

Bue Weintraub (1985), biz. 109. 
wan theorieen waarin irrationeel gedrag een rol speelt, of waarin evenwicht geen betekenis heeft, terwijl het toetsen van de hard core veronderstellingen niet aan de orde is. De protective belt is gevuld met een groot aantal modellen, die duizenden economen wereldwijd elke dag weer aan falsificatie onderwerpen. Een voorbeeld hiervan is het Capital Asset Pricing Model om het gedrag van financiele markten in kaart te brengen, een model waarop ik zo meteen in deze rede nog terugkom.

\section{VRAAG EN ANTWOORD}

De bestudering van zowel de gebeurtenissen omtrent de introductie van het aandeel World Online op de Amsterdamse effectenbeurs, alsmede het verschijnsel werkloosheid, resulteerde in vijf fundamentele vragen. Binnen de context van het ADM-model kunnen deze vragen met behulp van het inmiddels ontwikkelde begrippenapparaat scherp geformuleerd worden:

1. Bestaat er altijd een Walrasiaans evenwicht?

2. Kunnen ex meerdere Walrasiaanse evenwichten bestaan?

3. Convergeert het Walrasiaanse tâtonnement proces naar een Walrasiaans evenwicht?

4. Is een Walrasiaans evenwicht Pareto-efficiënt?

5. Is het mogelijk een Walrasiaans evenwicht te berekenen?

Het eerste vraagstuk staat bekend als de vraag naar evenwichtsexistentie. Wald (1936) was de eerste die dit probleem zorgvuldig aanpakte. Onder een aantal beperkende veronderstellingen slaagde Wald erin aan te tonen dat er inderdaad een (uniek) Wallrasiaans evenwicht bestaat. Een belangrijke basis voor generalisatie van de aanpak van Wald werd gelegd in von Neumann (1937), een artikel dat de vastpuntstelling van Brouwer (1912) binnen de economische wetenschap introduceerde. Beschouw ter illustratie van de vastpuntstelling van Brouwer een kopje koffie, waarin koffie met een lepel op willekeurige wijze door elkaar geroerd wordt. De vastpuntstelling van Brouwer beweert dan dat er op leder moment tijdens het roeren minstens een deeltje koffie zich op dezelfde plaats in het kopje bevindt als in de uitgangssituatie. Met behulp van de door Kakutani (1941) geformuleerde generalisatie van deze vastpuntstelling slaagden Arrow en Debreu (1954) erin een wiskundig bewijs te leveren voor het bestaan van een Walrasiaans evenwicht. De Walrasiaanse evenwichten komen overeen met de deeltjes koffie die op hun plaats blijven. 
De voorspelkracht van een model is op volle sterkte als het model voor iedere situatie een unieke voorspelling oplevert. Het is dus van belang om aan te tonen dat er een uniek Walrasiaans evenwicht is. Zonder bet maken van zware additionele aannamen, zie bijvoorbeeld Arrow en Hahn (1971), Hoofdstuk 9, is het onmogelijk uniciteit van het Walrasilaans evenwicht te garanderen. Het SMD-theorema impliceert dat vraagoverschotfuncties bijna geen structuur hebben, en daarmee dat de verzameling Walrasiaanse evenwichten er willekeurig ingewikkeld uit kan zien. Het is dus mogelijk dat er én Walrasiaans evenwicht is, maar twee kan ook, evenals drie, vier, of oneindig veel.

Enige hulp komt van Debreu (1970). Hij toont aan dat het weliswaar mogelijk is dat er oneindig veel Walrasiaanse evenwichten zijn, doch dat met $100 \%$ zekerheid, het aantal Walrasiaanse evenwichten eindig is. ${ }^{7}$ De bewering dat een situatie met $100 \%$ zekerheid optreedt, betekent hier niet dat andere situaties belemaal niet voor kunnen komen, maar wel dat andere situaties bijna nooit optreden. Bovendien variëren de Walrasiaanse evenwichten met $100 \%$ zekerheild op continue wijze met veranderingen in de primitieve concepten. Deze resultaten impliceren dat Walrasiaanse evenwichten vrijwel altijd lokaal uniek zijn en dat kleine veranderingen in de primitieve concepten leiden tot kleine veranderingen in de Walrasiaanse evenwichten. Dierker (1972) toont bovendien aan dat twee, vier, zes, of een ander even aantal Walrasiaanse evenwichten slechts in zeer exceptionele situaties optreedt. Het aantal Walrasiaanse evenwichten is met $100 \%$ zekerheid een eindig, oneven aantal.

Evenwichtsexistentie is een fraai resultaat. Dat is echter nog geen garantie dat een Walrasiaans evenwicht tot stand komt. Een bewijs van convergentie wan het Walrasiaanse tâtonnement proces naar een Walrasiaans evenwicht, zou het geloof in Walrasiaanse evenwichten versterken. In het geval van het bestaan van meerdere Walrasiaanse evenwichten, verkrijgt men dan bovendien meer inzicht in de vraag welk Walrasiaans evenwicht tot stand komt. De eerste artikelen met condities waaronder het Walrasiaanse tâtonnement proces naar een Walrasiaans evenwicht convergeert, zijn Arrow en Hurwicz (1958) en Arrow, Block en Hurwicz (1959). Ofschoon de daar gevonden condities nog niet het algemene geval overdekten, stemden deze resultaten toch hoopwol, zie Arrow en Hurwicz $(1958)$, blz. 530:

On the other hand, none of the results so far obtained con-

${ }^{T}$ De werzameling economieën waarbij een oneindig aantal Walrasiananse evenwich ten bestaat heeft een afolluiting met Lebesgue mat nul. 
tradicts the proposition that under perfect competition, with the customary assumptions as to convexity, etc., the system specified is always stable.

Niet veel later echter introduceerde Scarf (1960) zijn beroemde voorbeeld van een economie die aan alle gebruikelijke veronderstellingen voldoet, maar waarin prijsaanpassing wolgens het Walrasiaanse tâtonnement proces niet tot convergentie naar een Walrasiaans evenwicht leidt. In eerste instantie kon het tegenvoorbeeld van Scarf nog worden afgedaan als zijnde een uitzonderingsgeval. Het SMD-theorema van begin jaren zeventig laat zien dat de vraagoverschotfunctie willekeurig kan zijn, en daarmee dat alle vormen van gecompliceerd dynamisch gedrag kunnen optreden. Zonder een afdoende antwoord op de vraag hoe een Walrasiaans evenwicht tot stand komt, kan het merendeel van het momenteel gedane economisch onderzoek in de prullenbak verdwijnen. Hildenbrand (1989), blz. 259, schrijft:

If the laws in physics, say the laws in aerodynamics, were founded in this way, I would never sit in a plane.

Economen hebben er echter massaal voor gekozen hun kop in het zand te steken, en door te gaan met het doen van woorspellingen op basis van veranderingen in het evenwicht. Het blijft verbazingwekkend dat er niet meer aandacht is voor alternatileve onderzoekslijnen met een serieuze analyse van handel en prijszetting van bedrijven en huishoudens buiten het evenwicht. Een volledig uitgewerkte theorie is op dit gebied nog niet voorhanden. Veelbelovende ingrediënten voor een dergelijke analyse zijn te vinden in Hahn en Negishî (1962), Uzawa (1962), Fisher (1983) en Schinkel, Tuinstra en Vermeulen (2000).

Naar mijn mening zijn er op dit moment twee wegen om het neoWalrasiaanse onderzoeksprogramma overeind te houden. De eerste mogelijkheid is om in plaats van het maken van aannamen op individuele karakteristieken van huishoudens en bedrijven, aannamen te maken op de verdeling van dergelijke karakteristieken. Er zijn aanwijzingen dat de aanwezigheid van voldoende diversiteit in de economie tot betere convergentie-eigenschappen van het Walrasiaanse tâtonnement proces leidt. Hildenbrand (1983) laat zien dat bij bepalde vormen van diversiteit in inkomens, vraagoverschotfuncties voldoen aan de wet van de vraag. Deze wet houdt in dat prijsveranderingen en vraagveranderingen op negatieve wijze samenhangen. De wet van de vraag is een voldoende voorwaarde voor convergentie van het Walrasiaanse tâtonnement pro- 
ces naar een Walrasiaans evenwicht, en zelfs yoor uniciteit van Walrasiaanse evenwichten. Grandmont (1992) bekijkt het geval van diversiteit in voorkeursrelaties. Hij leidt een nog sterker resultaat af dan Hildenbrand. Een economie waarin huishoudens sterk uiteenlopende voorkeursrelaties hebben, heeft dezelfde eigenschappen als een economie met één enkele agent, die een zogenaamde Cobb-Douglas voorkeursrelatie heeft. In dat geval is zeker aan de wet van de vraag voldaan, en convergeert het Walrasiaanse tâtonnement proces naar het unieke Walrasiaanse evenwicht.

De tweede route ter verdediging van het neo-Walrasiaanse onderzoeksprogramma bestaat uit de observatie dat het Walrasiaanse tâtonnement proces niet het enig mogelijke proces is dat de aanpassing van prijzen beschrijft. Het zou kunnen zijn dat andere prijsaanpassingsprocessen betere convergentie-eigenschappen hebben. Saari en Simon (1978) beschouwen een groot aantal mogelijke prijsaanpassingsprocessen. Zij concluderen dat convergentie uitgesloten is, tenzij het aanpassingsproces zeer veel informatie gebruikt, waaronder informatie over bijna alle eerste afgeleiden van de vraagoverschotfunctie. De vraag blijft echter of zelfs met gebruikmaking van al die informatie, er altijd convergerende aanpassingsprocessen bestaan. Het aanpassingsproces van Smale (1976) convergeert bijna altijd naar een Walrasiaans evenwicht als de initiële prijzen geschikt gekozen zijn. Is dat laatste niet het geval, dan volgt uit Keenan (1981) dat convergentie niet hoeft op te treden. Kamiya (1990) beschrijft een mengsel van het Walrasiaanse tâtonnement proces en het aanpassingproces van Smale (1976). Hierbij geschiedt prijsaanpassing initieel volgens het eerste proces, en uiteindelijk volgens het tweede. Kamiya toont convergentie van zijn proces naar een Walrasiaans evenwicht aan onder niet onredelijke aannamen op de economie en voor bijna alle initiële prijzen.

Het eerste bewijs van convergentie van een aanpassingsproces onder standaardaannamen op de economie en voor bijna alle initiële prijzen staat in Herings (1997b). In dat artikel laat ik zien dat het in Van der Laan en Talman (1987) geïntroduceerde proces deze sterke convergentieeigenschappen bezit. Ik toon verder aan dat als aan de in Arrow, Block en Hurwicz (1959) beschouwde aanname van bruto-substitueerbaarheid voldaan is, het gedrag van dit aanpassingsproces gelijkenis vertoont met het Walrasiaanse tâtonnement proces. Herings (2000) legt het mechar nisme bloot dat zorgt voor de goede convergentie-eigenschappen. Dit artikel maakt het ook volstrekt duidelijk dat er vele altijd convergerende prijsaanpassingsprocessen zijn. Het blijft natuurlijk de wraag welk van al de genoemde processen het best de decentrale prijsaanpassing zoals die 
plaatsvindt in een vrije markteconomie beschrijt. Wat ook het antwoord op deze vraag moge zijn, het bestraan van altijd convergerende prijsaanpassingsprocessen maakt duidelijk dat men vraagtekens moet plaatsen bij het niet convergeren van al te mechanische prijsaanpassingsprocesBen zoals het Walrasiaanse tâtonnement proces. Ofschoon er dus twee wegen zijn om het neo-Walrasiaanse bolwerk overeind te houden, is het gebaseerd op wankele fundamenten.

Arrow (1951) en Debreu (1951) toonden onafhankelijk van elkaar aan dat een Walrasiaans evenwicht altijd Pareto-efficiënt is. Als de economie in een Walrasiaans evenwicht verkeert, is het voor de overheid niet mogelijk groeperingen in de samenleving erop vooruit te laten gaan, zonder dat anderen er daardoor op achteruit gaan. Ik durf de stelling aan te gaan dat er geen ander resultaat binnen de economische wetenschap bestaat met een grotere invloed op de organisatie van de samenleving. Eén van de meer recente voorbeelden van die invloed is het project "Marktwerking, deregulering en wetgevingskwaliteit," waarin de regering zich onder andere ten doel stelt de marktwerking in tal wan sectoren te versterkem. Een ieder van ons heeft de gevolgen van dit project bijvoorbeeld ondervonden in de vorm van de ingevoerde concurrentie binnen de mobiele telefoniesector.

Eên methode om Walrasiaanse evenwichten uit te kunnen rekenen is ouder dan menigeen hier aanwezig zal vermoeden. In 1893, dus ruim yoor de uitvinding van de computer, bouwde de econoom Irving Fisher reeds een machine, waarmee hij in staat was Walrasiaanse evenwichten uit te rekenen voor economieën met drie huishoudens en drie goederen. ${ }^{8}$ De inkomens van de huishoudens hangen niet af van de prijzen van de goederen, maar liggen vast. De totaal beschikbare hoeveelheid van elk goed ligt ook vast. Bovendien hebben de huishoudens zogeheten separabele voorkeursrelaties. Dit levert nog steeds een zeer ruime klasse van economieèn op, waarin bijwoorbeeld meerdere Walrasiaanse evenwichten voor kunnen komen. Fisher beschrijft bovendien hoe uitbreidingen met productie, en uitbreidingen tot een willekeurig aantall goederen en huishoudens kunnen geschieden.

De machine van Fisher bestaat uit negen vazen in een bak met water. Er is cen aparte vaas woor iedere combinatie van een goed en een huishouden. Er zijn daarom drie vazen per huishouden en drie vazen per goed. De voorkeursrelatie van een huishouden legt de vorm van

"Voor een gedetailleerde beschrijwing wan de machine, alsmede foto's van twee gebouwde exemplaren, zie Fisher (1925). 
diens drie vazen vast. Iedere vaas bestaat uit twee compartimenten. De hoeveellheid water in het voorste compartiment bepaalt de hoeveelheid die het huishouden van dat goed consumeert. De hoeveelheid water in het achterste compartiment geeft de hoeveelheid inkomen aan die het huishouden aan consumptie van dat goed besteedt. Het achterste compartiment heeft een flexibele dikte. De dikte van dat compartiment correspondeert met de prijs van het goed. Van alle drie de vazen corresponderende met een bepaald goed zijn de voorste compartimenten onderling met elkaar verbonden. De totale hoeveelheid water in deze compartimenten is gelijk aan de totaal aanwezige hoeveelheid van dat goed. Van alle drie de vazen corresponderende met een bepaald huishouden zijn de achterste drie compartimenten onderling met elkaar verbonden. De totale hoeveelheid water in deze compartimenten is gelijk aan het totale inkomen van dat huishouden.

Zolang het water niet in alle negen vazen op hetzelfde niveau statat als het water in de omringende bak, zullen sommige vazen verder of minder ver in het water zakken, zal de dikte van de achterste compartimenten van de vazen toe- of afnemen, en zal water wan de ene vaas naar de andere stromen. Dit proces gaat door totdat het water in alle negen vazen op hetzelfde niveau staat als het water in de omringende bak. De machine is zo geconstrueerd dat dit alleen kan als de hoeveelheden water in de vazen overeenkomen met een Walrasiaans evenwicht. Fisher had hiermee dus het eerste bewijs van evenwichtsexistentie en van een altijd convergerend prijsaanpassingsproces.

Modernere manieren om een Walrasiaans evenwicht te berekenen, vinden hun oorsprong in de bijdrage van Scarf (1967). Scarf presenteert een wiskundige methode om een vast punt, waarvan het bestaan volgt uit de vastpuntstelling van Brouwer, daadwerkelijk uit te kunnen rekenen. Dit maakt de methode van Scarf geschikt om een Walrasiaans evenwicht te berekenen.

De essentie achter de methode van Scarf komt overeen met het vinden van een kamer met slechts één deur in een spookhuis. Het spookhuis heeft een groot, doch eindig, aantal kamers. Er is geen enkele kamer met drie of meer deuren. Dus iedere kamer heeft of geen, of éen, of twee deuren. Er is precies én kamer met een buitendeur, waardoor u het spookhuis binnenkomt. Bowendien wordt $u$ achterna gezeten door een spook. Omkeren kan dus niet. Om onverklaarbare redenen durft het spook kamers met én deur niet te betreden. In kamers die slechts én deur hebben bent $\mathrm{u}$ dus veilig, maar $\mathrm{u}$ weet niet eens of dergelijke kamers. bestaan. 
Als de kamer waar u via de buitendeur binnenkomt slechts één deur heeft, bent $u$ onmiddellijk veilig. Zo niet, dan heeft deze kamer precies nog één deur, en omdat $\mathrm{u}$ achterna gezeten wordt door het spook is dat uw enige vluchtweg. De kamer die u nu binnentreedt heeft minstens één deur, te weten de deur waardoor u binnenkwam. Als deze kamer geen andere deur heeft, bent $u$ van het spook gevrijwaard. De enige andere mogelijkheid is dat deze kamer nog één deur heeft, wederom de enige manier om aan het spook te ontsnappen. Op deze wijze doolt u rond in het spookhuis, op zoek naar een kamer met éen deur. Er zijn nu twee mogelijkheden. Of u vindt inderdaad een kamer met slechts één deur, of u snelt eeuwig van kamer tot kamer. Stel dat het laatste het geval is. Omdat het aantal kamers eindig is, betreedt $u$ op een zeker moment een bepaalde kamer woor de tweede keer. Beschouw de eerste kamer waar $\mathrm{u}$ voor de tweede keer binnenkomt. De deur waardoor $\mathrm{u}$ deze kamer binnenkomt, moet een andere zijn dan waardoor u deze kamer voorheen binnenkwam of verliet. Anders zou de vorige kamer waar u was de eerste zijn die u twee keer betrad. Maar dan moet de kamer waar u nu bent minstens drie deuren hebben. Het spookhuis heeft echter geen enkele kamer met zoveel deuren. Kortom, het is onmogelijk dat u eeuwig rond blijft dolen. Op een zeker moment vindt $u$ een kamer met slechts één deur.

Ik had u niet verteld dat een kamer met precies één deur inderdaad bestond. Ieder spookhuis dat u bouwt met precies één buitendeur, en met geen enkele kamer met drie of meer deuren, moet dus een kamer met precies één deur hebben. Sterker nog, er zal een oneven aantal kamers met precies één deur zijn. Inderdaad, wanneer u begint te lopen in een kamer met precies één deur kan met dezelfde redenering als zojuist worden aangetoond dat $\mathrm{u}$ of bij de buitendeur komt, of bij een andere kamer met precies één deur. Alle kamers met één deur en de kamer met de buitendeur kunnen gegroepeerd worden in met elkaar verbonden paren. Het totaal aantal kamers met precies éen deur of de buitendeur is daarom even, zodat het totaal aantal kamers met precies één deur oneven is. Wanneer Scarf's methode wordt toegepast op een algemeen evenwichtsmodel komen de kamers met éen deur overeen met Walrasiaanse evenwichten. De redenering dat er een oneven aantal kamers met eén deur is, leidt tot de conclusie dat er een oneven aantal Walrasiaanse evenwichten is.

Er bestaat een groot aantal algoritmen die gebaseerd zijn op de methode van Scarf (1967) en die daarop verdere verfijningen aanbrengen met als doel de rekentijd te verminderen. Het grootste nadeel van de 
methode van Scarf is dat het niet mogelijk is om eventueel beschikbare informatie over de locatie van een Walrasiaans evenwicht te benutten. Als met de rekenmethode van Scarf een niet geheel tevreden stellende benadering van een Walrasiaans evenwicht gevonden is, moet men weer helemaal vain voren af aan beginnen met rekenen. De homotopiemethode van Eaves (1972), de sandwichmethode van Kuhn en MacKinnon (1975), en het variabele dimensie algoritme van Van der Laan en Talman (1979) komen aan dit probleem tegemoet doordat ze iedere benadering vain een Walrasiaans evenwicht als startpunt van hun algoritme kunnen nemen.

Het basisprincipe achter het eerder genoemde prijsaanpassingsproces in Herings (1997b) komt ook overeen met dat van het spookhuis. Een belangrijk bijkomend probleem is echter dat nu sommige kamerss wel drie of meer deuren kunnen hebben en dat sommige deuren toegang kunnen bieden tot twee of meer kamers tegelijkertijd. Dat zijn gevaarlijke spookhuizen, omdat $u$ in een dergelijk spookhuis niet altijd in een veilige kamer met precies één deur terechtkomt. De oplossing voor deze problemen komt tot stand met behulp van argumenten uit de differentiaal-topologie. Hierbij was het werk van Jongen, Jonker en Twilt (1983, 1986) mij zeer behulpzaam. Met behulp van deze argumenten kon ik aantonen dat er weliswaar gevaarlijke spookhuizen bestaan, maar dat het aantal gevaarlijke spookhuizen verwaarloosbaar klein is. Met $100 \%$ zekerheid bevindt $\mathbf{u}$ zich in een veilig spookhuis.

\section{Onvolledige MARKTEN}

In de beschrijving van het ADM-modlel heb ik de woorden tijd en onzekerheid grotendeels vermeden. Toch zijn tijd en onzekerheid belangrijke en niet te verwaarlozen elementen binnen de economie. Hoofdstuk 7 van Debreu (1959) neemt tijd en onzekerheid mee in de beschrijving van goederen. Een goed is dan niet langer de arbeid van een hoogleraar microeconomie, maar bijvoorbeeld arbeid van een hoogleraar micro-economie op 19 juni 2000 die zijn oratie op 16 juni 2000 tot een goed einde heeft gebracht, of bijwoorbeeld arbeid van een hoogleraar micro-economie op 19 juni 2000 die zijn oratie op 16 juni 2000 niet heeft weten te voltooien. Ook de uitslag van de voetbalwedstrijd Denemarken-Nederland op 16 juni 2000, in welke minuten gescoord is en door wie, wordt een onderdeel van de beschrijving van toekomstige goederen. Door aan te nemen dat

Een gedetailleerde beschrijving van deze algoritmen alsmede de huidige stand wan zaken op dit gebied is te vinden in Scarf en Herimgs (1998). 
in elk van de zo verkregen goederen op dit moment gehandeld kan worden, en er voor elk van deze goederen een prijs tot stand komt, valt tijd en onzekerheid geheel binnen het ADM-model, dat dan overigens het Arrow-Debreu (AD) model genoemd wordt.

Deze modellering van tijd en onzekerheid is echter erg kunstmatig. Volgens het $\mathrm{AD}$-model maken alle huishoudens en bedrijven reeds op dit moment volledig uitgewerkte plannen die rekening houden met alle vormen van onzekerheid die eventueel op zouden kunnen treden. In een dergelijke wereld zijn aandelenmarkten volstrekt overbodig. Verrassingen, dat wil zeggen onvoorziene gebeurtenissen, zijn uitgesloten. Zoals Werner Hillenbrand opmerkt in zijn voorwoord bij Magill en Quinzii (1996):

Time and uncertainty was treated in an amazingly simple way. This simplicity was achieved by postulating a highly idealized market structure, the Arrow-Debreu complete system of contingent contracts. But invoking this hypothesis dispenses with the modelling of expectations of what the future has in store - and gone are the joys of life.

Het systeem van markten waarbij voor alle goederen een markt bestaat, staat bekend als een systeem met volledige markten. Een systeem met volledige markten vereist dat ook voor alle pas in de toekomst beschikbare goederen een markt bestaat. Hierbij dient bovendien de uitkomst van alle mogelijke onzekere toekomstige gebeurtenissen in de beschrijving van het goed gespecificeerd te worden.

Er zijn minstens drie redenen waarom het marktsysteem niet zo uitgebreid is als het AD-model ons wil doen geloven. Ten eerste zijn huishoudens en bedrijven begrensd rationeel. Ze zijn niet in staat de hele toekomst te voorzien, en nu al plannen op te stellen voor alle mogelijke gebeurtenissen. Ze beperken zich daarom tot die goederen, waarvan ze de toekomstige consequenties goed kunnen inschatten. Ten tweede zijn de transactiekosten van een systeem van volledige markten veel te hoog. Het is zeer kostbaar en omslachtig om te handelen in de complexe goederen die een systeem van volledige markten nodig heeft. En ten derde zijn er problemen met asymmetrische informatie. Goederen waarvan de beschrijving informatie bevat die niet voor alle marktpartijen te verifëren is, worden meestal niet verhandeld. U kunt geen verzekering afsluiten tegen het verlies van een tientje, omdat het voor geen enkele verzekeringsmaatschappijj na te gaan valt of $u$ dat tientje daadwerkelijk werloren hebt. 
Een realistischer model erkent dat huishoudens en bedrijven slechts in beperkte mate financiêle verplichtingen voor wat betreft de toekomst willen aangaan. De aanwending van hun financiële middelen valt op ieder moment in de tijd in twee onderdelen uiteen. Ten eerste beslissen ze over de verdeling ervan ten behoeve van consumptie en productie op dat moment versus consumptie en productie in de toekomst. Huishoudens en bedrijven kunnen dit doen door geld in financiële vermogenstitels te investeren, bijwoorbeeld door te sparen of te beleggen, of door geld aan de financiële markten te onttrekken, bijwoorbeeld door geld te lenen of door aandelen te emitteren. De onvolledigheid van financiële markten houdt in dat het aantal financiële producten waaruit huishoudens en bedrijwen kunnen kiezen beperkt is. Dat sluit niet uit dat dit aantal nog steeds zeer groot kan zijn. Ten tweede beslissen huishoudens en bedrijven hoe ze financiële middelen die beschikbaar zijn voor consumptie en productie op dat moment, over de verschillende goederen verdelen. Een algemeen evenwichtsmodel dat tijd en onzekerheid serieus neemt, alsmede de modellering van de financiële sector, is het algemeen evenwichtsmodel met onvolledige markten (GEI) ${ }^{10}$ Het GEI-model vormt een raamwerk dat het mogelijk maakt een groot aantal problemen uit de micro-economie, de macro-economie en de financiering op een systematische en gelijksoortige manier te analyseren.

Het GEI-model werpt een groot aantal traditionele inzichten uit het AD-model omver. Winstmaximalisering van bedrijven bij gegeven prijzen hoeft niet langer in het belang van aandeelhouders te zijn, monetair beleid heeft niet slechts invloed op de hoogte van de prijzen, maar ook op consumptie- en productiehoeveelheden, en onzekerheid omtrent. niet-economische verschijnselen ("zonnevlekken") kan een reële invloed. hebben op de economie. Ook de antwoorden op de eerder genoemde vijf fundamentele vragen zien er bij het GEI-model anders uit.

Radner (1972) formuleerde het prototype van het GEI-model evenals het bijbehorende evenwichtsconcept, waarmee hij de bijdrage van Arrow (1953) generaliseerde. Een evenwicht bestaat uit de prijzen van goederen en financiële vermogenstitels op dit moment, alsmede uit de verwachtingen van huishoudens en bedrijven omtrent dergelijke prijzen in de toekomst. Evenwichtsprijzen zijn zodanig dat vraag en aanbod van goederen en financiële vermogenstitels, nu en in de toekomst, aan elkaar gelijk zijn. Radner (1972) slaagde erin het bestaan van een evenwicht

${ }^{10}$ De Engelstalige literatur duidt dit model vaak an met General Equilibrium whth Incomplete Markets. 
aan te tonen, maar gebruikte daarbij een aanname op de begrensdheid van transacties in de financiële markten. Hart (1975) demonstreerde op vernietigende wijze het ongefundeerde karakter van deze aanname. Hij liet zien dat evenwichten niet hoeven te bestaan als deze aanname niet wordt gemaakt. Duffie en Shafer (1985) redden het model met een techniek die al enige malen aan de orde is geweest. Zij laten zien dat de ongewillige gevallen uitzonderingsgevallen zijn. In het GEI-model bestaat een evenwicht niet altijd, echter wel met $100 \%$ zekerheid.

Meerdere auteurs noemen transactiekosten als een belangrijke reden woor de onvolledigheid van markten. Toch spelen transactiekosten in de meeste modellen geen expliciete rol. Zoals Herings en Schmedders (2000) laten zien, leidt het modelleren van transactiekosten tot een aantal problemen, waaronder het optreden van een oneindig aantal evenwichten met positieve kans. De door Herings en Schmedders (2000) gekozen oplossing is afkomstig uit de speltheorie en bestaat uit het opleggen van een verfijning aan het evenwichtsconcept. Zij bewijzen dat er met $100 \%$ zekerheid zowel een eindig, oneven aantal aanbod-perfecte als een eindig, oneven aantal vraag-perfecte evenwichten is.

Het GEI-model bevat het AD-model als een bijzonder geval. Uniciteit van een evenwicht valt daarom in het algemeen niet te verwachten. Hens, Schmedders en Voss (1999) geven voldoende voorwaarden waaronder er een uniek evenwicht is. Hens (1995) beschrijft een aantal resultaten die analoog zijn aan het SMD-theorema. De structuur van de verzameling evenwichten kan wederom willekeurig ingewikkeld zijn. De bijdrage van Duffie en Shafer (1985) maakt echter wel duidelijk dat er met $100 \%$ zekerheid een eindig aantal evenwichten is, terwijl Brown, DeMarzo en Eaves (1996) aantonen dat dit aantal met $100 \%$ zekerheid oneven is.

De voor het ADM-model beschreven problematiek orntrent het tot stand komen van een evenwicht gaat onverminderd op. Zoals Hens (1997) en Herings (1999) laten zien, zijn er zelfs meerdere varianten van het Walrasiaanse tâtonnement proces denkbaar, met elk hun eigen voorwararden voor convergentie.

Veel beleidsgerichte economen ondersteunen het overheidsbeleid ter bevordering van marktwerking met een beroep op de Pareto-efficiëntie van Walrasiaanse evenwichten. Jammer genoeg voor hen zijn evenwichten in het GEI-model niet Pareto-efficiënt zoals Hart (1975) al liet zien. Dit is minder verrassend dan het op het eerste gezicht lijkt. Paretoefficiëntie is een begrip dat van volledigheid van markten uitgaat en stelt daarmee te hoge eisen. Ernstiger is het dat evenwichten niet eens beperkt Pareto-efficiënt zijn. Geanakoplos en Polemarchakis (1986) beoordelen 
de efficiëntie van evenwichten vanuit een perspectief dat rekening houdt met de onvolledigheid van markten. $\mathrm{Zij}$ concluderen dat aan een criterium van beperkte Pareto-efficiëntie met $100 \%$ zekerheid niet voldaan is.

Herings en Polemarchakis (1999) komen tot een soortgelijke conclusie. Met $100 \%$ zekerheid kan de overheid alle huishoudens erop vooruit laten gaan door in te grijpen in het prijsmechanisme, zelfs als dat werkloosheid tot gevolg kan hebben. De gedachte hierachter is dat in een wereld met onvolledige markten instrumenten als het minimumloon kunnen leiden tot vermindering van toekomstige inkomensonzekerheid, en daarmee welvaartsverbeteringen tot stand kunnen brengen. Dit soort resultaten impliceert overigens niet dat de overheid moet overgaan tot ingrijpen in het prijsmechanisme. Om alle huishoudens daadwerkelijk erop vooruit te laten gaan, is nogal wat informatie vereist. Informatie waarover de overheid vaak niet of slechts in beperkte mate beschikt. Het argument tegen overheidsingrijpen in een decentraal georganiseerde economie is nu wel behoorlijk verzwakt. Het gebruikelijke argument is dat het onmogelijk is dat zulk ingrijpen tot welvaartsverbeteringen leidt. Uitgaande van het GEI-model blijft slechts het argument over dat het onmogelijk is dat de overheid voldoende informatie heeft om welvaartsverbeteringen tot stand te brengen.

Het lukte Duffie en Shafer (1985) om het bestaan van een evenwicht in het GEI-model aan te tonen met bijzonder krachtig wiskundig gereedschap, dat in complexiteit ver uitstijgt boven de vastpuntstelling van Brouwer. Het is dan ook niet zo maar mogelijk om een evenwicht te berekenen met bijvoorbeeld Scarf's methode. Brown, DeMarzo en Eaves (1996) ontwikkelden een variant op de homotopiemethode van Eaves (1972), waarin niet één homotopie, maar een groot aantal homotopieën nodig is, en waarbij op de juiste momenten van homotopie gewisseld wordt. $\mathrm{Zij}$ tonen aan dat dit stelsel van homotopieën met $100 \%$ zekerheid een evenwicht berekent. Het blijft een open vraagstuk of het mogelijk is met behulp van eén enkele, slim gekozen, homotopie met $100 \%$ zekerheid een evenwicht te berekenen.

Ondat het GEI-model de financiele sector op een overtuigende manier modelleert, kan ik ook een antwoord geven op het vraagstuk of een belegger er verstandig aan had gedaan in te schrijven op het aandeel World Online. Het is mogelijk om iedere gewenste financiële vermogenstitel, zoals een staatsobligatie, het aandeel World Online, of een spaarrekening, binnen het GEI-model te modelleren. De evenwichtsprijzen van een financiële vermogenstitel in de loop der tijd, die mede afhangen van 
de uitkomst van een scala aan onzekere gebeurtenissen, verklaren het te werwachten rendement.

Sharpe (1964) en Lintner (1965) introduceerden het Capital Asset Pricing Model (CAPM) binnen de financieringstheorie. Dit model genereert twee belangrijke resultaten. Ten eerste geldt dat het te verwachten rendement van elke financiele vermogenstitel gelijk is aan het rendement vari een risicovrije obligatie plus de $\beta$ van de financiële vermogenstitel maal het te verwachten rendement op de marktportefeuille. De $\beta$ is een maat voor het rísico van de vermogenstitel en is gelijk aan de covariantie van het rendement van die vermogenstitel en het rendement van de marktportefieuille gedeeld door de variantie van het rendement van de marktportefeuille. De marktportefeuille is het totaal van vermogenstitels dat op de financiële markten verhandeld wordt. Het tweede resultaat van het CAPM is dat alle rationele beleggers op dezelfde wijze handelen. Ze verdelen hun gehele vermogen over slechts twee typen financiële vermogenstitels: de risicovrije obligatie en de marktportefeuille.

Geanakoplos en Shubik (1990) laten zien dat het CAPM een bijzonder geval is van het GEI-model. Bovendien blijkt door de behandeling als een bijzonder geval hoe restrictief de aannamen zijn die aan het CAPM ten grondslag liggen, bijvoorbeeld dat alle vermogenstitels normaal verdeelde rendementen hebben of dat alle beleggers alleen belang hechten aan de verwachting en de variantie van hun verdiensten. In werkelijkheid is aan geen van beide aannamen voldaan, zodat het geen verbazing lijkt te wekken dat menig empirische studie het CAPM verwerpt, zie bijvoorbeeld Fama en French (1992). Herings en Kubler (1999) stellen zich de vraag hoe goed het CAPM de evenwichten beschrijft in een GEI-model dat de Amerikaanse economie weerspiegelt, zonder daarbij de restrictieve aannamen te maken die het CAPM kenmerken. Hiertoe ontwikkelen zij een nieuw algoritme dat een evenwicht in de financieringsversie van het GEI=model snel en effectief berekent. ${ }^{11}$ Het verbazingwekkende antwoord dat zij vinden, is dat het CAPM een buitengewoon goede beschrijving geeft van te verwachten rendementen en rationeel investeringsgedrag. Omdat het aandeel World Online een onderdeel is van de marktportefeuille, betekent dit dat beleggers er verstandig aan doen om dit aandeel aan te kopen! Echter, aangezien het belang van dit aandeel in een wereldwijde marktportefeuille verwaarloosbaar klein is, komt dit advies voor de meeste beleggers overeen met niet

${ }^{11}$ In de financieringsversie wan het GEI-model heeft ieder huishouden en ieder bedrijf op ieder beslisingsmoment, naast een willekeurig aantal financiële vermogenstitels, slechts een goed ter beschikking voor consumptie- en productiedoeleinden. 
kopen.

\section{PRIJSSTARHEDEN EN COÖRDINATIEPROBLEMEN}

Ik heb reeds beargumenteerd dat de inflexibiliteit van lonen een belang. rijke verklaring is voor het bestaan van werkloosheid. Dit past slecht in de tot nu toe besproken modellen, waar prijzen voortdurend veranderen om gelijkheid van vraag en aanbod van alle goederen en financiële vermogenstitels te bewerkstelligen. De eerste algemeen evenwichtsmodellen waarin het mogelijk is dat de prijsvorming imperfecties zoals prijsstarheden vertoont, zijn ontwikkeld door Bénassy (1975), Drèze (1975) en Younès (1975). ${ }^{12}$ Silvestre (1982) laat zien dat in veel gevallen de drie formuleringen tot identieke resultaten leiden. De formulering van Drèze (1975) is het meest algemeen en het eenvoudigst hanteerbaar. Vandaar dat ik er de voorkeur aan geef om deze benadering te volgen. Het model van Drèze is rijk genoeg om vele vormen van prijsstarheden te kunnen analyseren, zoals bijwoorbeeld gevallen waarin prijzen volledig: vast liggen, prijzen volledig flexibel zijn, of prijzen niet opwaarts maar wel neerwaarts star zijn. Dat laatste geval wordt vaak voor lonen als realistisch gezien.

Stel dat lonen neerwaartse starheden vertonen, en dat de prijzen van alle andere goederen volledig flexibel zijn. Zolang er een tekort aan arbeidskrachten is, is er niets bijzonders aan de hand. Het prijsmechanisme zorgt voor een opwaartse druk op de lonen, hetgeen de vraagoverschotten naar arbeid wegwerkt. In het meer interessante geval dat er een overschot aan arbeidskrachten is, zou een loondaling moeten zorgen voor gelijkheid van vraag en aanbod van arbeid. Bij neerwaartse starheden van lonen is dat echter onmogelijk. Het gevolg is dat het aanbodoverschot van arbeid blijft bestaan. Sommige aanbieders van arbeid zullen erachter komen dat hun aambod niet gebruikt wordt. Zij worden werkloos, of in de terminologie van het model, gerantsoeneerd op hun arbeidsaanbod. Dit heeft gevolgen voor alle andere markten. Rantsoenering van bepaalde typen arbeid kan extra aanbod van andere soorten arbeid uitlokken. Hierdoor kan werkloosheid ontstaan voor typen arbeid, waarwoor dat eerst niet het geval was. Het soms gesignaleerde verdringingseffect, waarbij hooggeschoolden laaggeschoolde arbeid verrichten, is hiervan een woorbeeld. Ook valt te werwachten dat de door werkloosheid veroorzaakte inkomensdaling leidt tot een vraagverminde-

${ }^{12}$ Herings (1996b) geeft een uitgebreid overzicht van deze literatuur. 
ring naar overige goederen. De prijzen van overige goederen dalen dan om deze markten weer in evenwicht te brengen. Het blijkt wederom dat de onderlinge afhankelijkheid van markten van groot belang is.

De definitie wan een evenwicht behoeft een aampassing in het algemeen evenwichtsmodel met prijsstarheden. Waar het eerst volstond om het stelsel van evenwichtsprijzen te specificeren als karakterisering van een evenwicht, dient nu bovendien voor iedere markt aangegeven te worden of er sprake is van rantsoenering op de vraag of rantsoenering op het aanbod. In een evenwicht kunnen beide soorten rantsoenering niet gelijktijdig op een markt optreden. Een gerantsoeneerde vrager en een gerantsoeneerde aanbieder zullen dan namelijk beseffen dat het mogelijk is met elkaar te handelen, waardoor beiden erop vooruitgaan. Ook is rantsoenering op het aanbod wan een goed alleen dan mogelijk als de prijs van dat goed een neerwaartse starheid vertoont, en rantsoenering op de vraag alleen als er sprake is van een opwaartse starheid. In het model is tevens een goed aanwezig, numéraire genaamd, dat dient als rekeneenheid en als ruilmiddel. Er vindt geen rantsoenering van de numéraire plaats. Een dergelijk evenwicht heet een Drèze-evenwicht.

Het is dus mogelijk om onevenwichtigheden als werkloosheid te bestuderen met een evenwichtsmodel! Dit model voldoet aan de door Weintraub (1985) geformuleerde veronderstellingen van het neo-Walrasiaanse onderzoeksprogramma. In het bijzonder aun de zesde veronderstelling, dat waargenomen economische uitkomsten gecoördineerd zijn en dat ze besproken dienen te worden met een verwijzing naar evenwichtstoestanden, is voldaan. Ik zou echter willen voorstellen nog een zevende veronderstelling aan het neo-Walrasiaanse onderzoeksprogramma toe te voegen, te weten dat alleen prijsaanpassingen zorgen voor het afstemmen van vraag en aanbod op markten. In dat geval maakt het algemeen evenwichtsmodel met prijsstarheden geen onderdeel uit van het neoWalrasiaanse onderzoeksprogramma. Dit model is een onderdeel van de hard core van een neo-Keynesiaans onderzoeksprogramma, waarin ook een rol is weggelegd voor hoeveelheidsaanpassingen bij het afstemmen van vraag en aanbod.

Een zwakte van het algemeen evenwichtsmodel met prijsstarheden is dat het geen verklaring biedt voor het optreden van prijsstarheden. Prijsstarheden zijn exogeen gegeven in dit soort modellen. Een belangrijk thema voor toekomstig onderzoek betreft het endogeen verklaren van prijsstarheden, waarbij de eerder genoemde elementen als de macht van vakbonden of werkgeversverenigingen, of de relatie tussen loon en productiviteit uit het model zelf volgen. Twee mogelijke verklaringen 
voor het optreden van prijsstarheden volgen uit mijn eigen werk. In Herings (1997a) breid ik het algemeen evenwichtsmodel met prijsstarheden uit met een model van de politieke sector. Politieke partijen maken hun keuzes onder invloed van de druk van kiezers. Politieke belangen vallen hierdoor niet samen met het maximaliseren van welvaart, zoals dat tot uitdrukking komt in het criterium van Pareto-efficientie. Het is met $100 \%$ zekerheid mogelijk om stemmen te winnen door het opleggen van prijsstarheden, met het minimumloon als prominent voorbeeld, zelfs als dat ten koste gaat van de totale welvaart in een land.

Een andere verklaring volgt wit Drèze en Gollher (1993) en het al genoemde werk van Herings en Polemarchakis (1999). Als markten onvolledig zijn, leidt de wrije markt in het algemeen miet tot Paretoefficiëntie. Prijsstarheden, zoals minimumlonen, maar ook langdurige arbeidscontracten, of langdurige contracten met leveranciers, kunnen dan gebruikt worden als vangnet tegen ontroorziene risico"s. De samenhang met onvolledige markten behoeft geen bewijs. In de aanwezigheid van een stelsel van volledige markten kunnen huishoudens en bedrijven zich perfect verzekeren tegen alle mogelijke toekomstige gebeurtenissen, en zijn langdurige contracten overbodig. Drèze (1999) geeft een heldere uiteenzetting van het samenspel tussen onvolledige markten en prijsstarheden.

Een analyse van de inmiddels bekende vijf fundamentele vragen voor het algemeen evenwichtsmodel met prijsstarheden levert het volgende op. Het bestaan van Drèze-evenwichten volgt uit het werk van Drèze (1975). De gebruikte technieken komen overeen met die voor het ADMmodel. Dat betekent onder meer dat evenwichtsberekening mogelijk is met het algoritme van Scarf (1967) en alle varianten ervan. Een aan het SMD-theorema analoge stelling gaat niet op. De vraagoverschotfunctie in het model van Drèze heeft de structurele eigenschap dat een toename van rantsoenering op de vraag van een goed, of een afname van rantsoenering op het aanbod van een goed, leidt tot een lager vraagoverschot. Desalniettemin is er weinig hoop op uniciteit van evenwichten, en zijn de in Laroque en Pollemarchakis (1978) en Herings (1996b) verkregen resultaten dat er met $100 \%$ zekerheid een eindig respectievelijk en oneven aantal evenwichten bestaat het maximaal haalbare.

Om soortgelijke redenen is er weinig hoop op conwergentie naar een Drèze-evenwicht van een equivalent van het Walrasiaanse tatonnement proces voor economieën met prijsstarheden. Herings, Van der Laan, Talman en Venniker (1997) en Herings, Van der Laan en Venniker (1998) laten zien dat het mogelijk is om een altijd naar een Drèze-evenwicht 
convergerend prijs- en hoeveelheidsaanpassingsproces te ontwerpen voor dit soort economieën, en ook hoe vervolgens de economie van een Drèzeevenwicht uiteindelijk in een Walrasiaans evenwicht kan geraken.

Als prijzen starheden vertonen die Walrasiaanse evenwichten uitsluiten, zullen weinig economen verwachten dat Drèze-evenwichten $\mathrm{Pa}$ reto-efficiënt zijn. De relevante vraag is echter, analoog aan het GEImodel, of Drèze-evenwichten beperkt Pareto-efficiënt zijn. Kan de overheid alle huishoudens erop vooruit laten gaan met in achtneming van de vigerende prijzen? Zoals Drèze en Müller (1980) aangeven, kan dit van geval tot geval verschillen. Zij gaan daarom over tot het analyseren van alternatieve evenwichtsconcepten. Böhm en Müller (1977) geven concrete voorbeelden van Drèze-evenwichten waarvoor beperkte Pareto-efficiëntie niet opgaat, en Maskin en Tirole (1984) karakteriseren Drèze-evenwichten die niet beperkt Pareto-efficiënt zijn. De vraag is of het wederom mogelijk is om te komen tot een resultaat dat stelt dat Drèze-evenwichten met 100\% zekerheid niet beperkt Pareto-efficiënt zijn. Herings en Konovalow (2000) laten zien dat dit resultaat opgaat als het aantal verhandelde goederen groter dan of gelijk is aan drie. Zijn er slechts twee goederen, een geval dat in de literatuur nogal eens bekeken wordt, dan gavat beperkte Pareto-efficiëntie wel altijd op.

De algemeen evenwichtstheorie met prijsstarheden laat zien dat er inefficiënties optreden bij handel tegen niet-Walrasiaanse evenwichtsprijzen. Het is echter niet vanzelfsprekend dat prijsstarheden het hele verhaal achter werkloosheid weergeven. Een interessante vraag is of werkloosheid ook zou kunnen optreden bij Walrasiaanse prijzen. In dat geval is werkloosheid niet het gevolg van handel tegen verkeerde prijzen, maar van coördinatieproblemen. In de literatuur is het gangbaar om te spreken van coördinatieproblemen als er meerdere evenwichten bestaan, terwijl alle huishoudens deze evenwichten op dezelfde manier rangschikken op basis van hun voorkeursrelaties. Als de gemeenschap er niet in slaagt het beste evenwicht tot stand te brengen, faalt zij in haar coördinatie. Coördinatieproblemen ontstaan als huishoudens en bedrijven zichzelf vervullende pessimistische verwachtingen hebben. Coördinatieproblemen lijken op de argumenten van Keynes (1936) om werkloosheid te werklaren. In het model met prijsstarheden zijn coördinatieproblemen mogelijk, doch zijn geen veelvuldig voorkomend fenomeen.

Coordinatieproblemen spelen wel een grote rol in het door Herings en Drèze (1998) ontwikkelde model, dat geinspireerd is door eerder werk van Van der Laan (1982), Herings (1996a), Herings, Talman en Yang (1996), Drèze (1997) en Herings (1998). Het model van Herings en Drèze on- 
derscheidt twee typen goederen. Goederen waarvan markten zodanig georganiseerd zijn dat prijzen onmiddellijk reageren op veranderingen in vraag-en aanbodverhoudingen, en goederen waarvan de prijzen op korte termijn star zijn. De aandelenmarkt is een voorbeeld van een markt van het eerste type, de arbeidsmarkt is van het tweede type. Om. de aandacht toe te spitsen op coördinatieproblemen, is het gevall aarin de prijzen van het tweede type goederen weliswaar vast liggen, maar waarden hebben overeenkomstig een Walrasiaans evenwicht, het meest. interessant. Huishoudens en bedrijven kennen de waarden van alle prijzen, doch weten niet of deze prijzen corresponderen met een Walrasiaans evenwicht. Op de markten van het eerste type weten zij, door de specifieke wijze waarop deze markten georganiseerd zijn, dat ze hun hele aanbod van goederen kwijt kunnen. Op de markten van het tweede type weten zij dit niet, en dienen zij verwachtingen te vormen over de vraag naar de door hen aangeboden goederen. In het model van Herings en Drèze (1998) bestaan er oneindig veel evenwichten, waaronder een Walrasiaans evenwicht, maar ook evenwichten met willekeurig pessimistische verwachtingen wan huishoudens en bedrijven omtrent hun afzetmogelijkheden. Coördinatieproblemen zijn in dit model overvloedig aanwezig.

De vastpuntstelling van Brouwer volstaat niet langer om de resultaten in Herings en Drèze (1998) te bewijzen. Hiervoor is de stelling van Browder (1960) vereist, een generalisatie van de vastpuntstelling van Brouwer. Het is wederom mogelijk deze stelling te illustreren met behulp van het roeren in een kopje koffie. De vastpuntstelling van Brouwer houdt in dat er op ieder moment tijdens het roerproces een deeltje koffie is dat zich op dezelfde plaats bevindt als in de uitgangssituatie. Veronderstel nu dat we een grafiek maken waarin de deeltjes koffie die zich op een bepaald tijdstip in de uitgangssituatie bevinden uitzetten tegen dat tijdstip. De vastpuntstelling van Browder beweert nu dat deze grafiek een samenhangende verzameling koffiedeeltjes bevat die één in het begin met één op het eind op zijn plaats gebleven koffiedeeltje verbindt.

Een altermatieve stelling die gelijkwaardig is aan de vastpuntstelling van Browder volgt uit het werk van Herings en Talman (1998). Een illustratie daarvan treft u aan op de omslag van mijn inaugurale rede. Zoals u ziet zijn de linkerrand en de onderkant van het voorblad zwart gekleurd, terwijl de rechterrand en de bovenkant blauw zijn. Ook ziet u dat het mogelijk is een curve te trekken van de linkerbovenhoek naar de rechteronderhoek die grenst aan zowel het zwarte als aan het blauwe gebied. Ik beweer nu dat het altijd mogelijk is zo'n curve van de linkerbovenhoek naar de rechteronderhoek te trekken, ongeacht de inkleuring 
wan het binnenste van het voorblad. Ook is de stelling niet beperkt tot het relatief eenvoudige geval van de inkleuring van een rechthoek, maar gaat ze ook op voor de inkleuring van een blok, of zelfs een willekeurig blok met hogere dimensie.

In deze inaugurale rede heb ik gekozen voor een drietal deelgebieden van de algemeen evenwichtstheorie, het ADM-model, het GEI-model en het algemeen evenwichtsmodel met prijsstarheden. Deze modellen heb ik besproken aan de hand van een vijftal fundamentele vragen, waarop steeds wisselende antwoorden kwamen. Maar er is meer. Ook algemeen evenwichtsmodellen met overlappende generaties, geld zonder intrinsieke waarde, asymmetrische informatie en ondeelbare goederen kunnen rekenen op mijn interesse. Ook an een andere theorie die me de laatste jaren erg heeft bezig gehouden, de speltheorie, heb ik in deze rede geen aandacht kunnen besteden. Deze lange lijst van onderwerpen is een goede indicatie dat op het gebied van de fundamentele economische theorievorming nog veel werk te verzetten is. Ik zal me de komende jaren niet vervelen. 
Mijnheer de Rector Magnificus,

Rest mij nog het dankwoord.

Het College van Bestuur van de Universiteit Maastricht dank ik voor het in mij gestelde vertrouwen. Dit geldt eveneens voor de benoemingsadviescommissie en het bestuur van de Faculteit der Economische Wetenschappen en Bedrijfskunde die bij mijn benoeming een belangrijke rol hebben gespeeld. Ik prijs mij gelukkig een bijcrage te kunnen leveren aan het onderwijs en onderzoek van deze dynamische, succesvolle en in meerdere onderzoeken hooggewaardeerde faculteit.

Hooggeleerde Talman, hooggeleerde Van der Laan, beste Dolf, beste Gerard,

In 1990, ik was toen derdejaars student econometrie aan de Katholieke Universiteit Brabant, gaf jij, Dolf, mij het advies om het boek "Theory of Value" van Gérard Debreu te lezen. Zoals je vanmiddag hebt kunnen horen, was dat advies niet aan dovemansoren gericht. In 1991 startte ik bij jou met promotieonderzoek naar algemeen evenwichtsmodellen met prijsstarheden. Dat was geen slechte keuze. Alleen al het proefschrift heeft geleid tot een zevental artikelen in internationale toptijdschriften. Wie Talman zegt, zegt Van der Laan, of eigenlijk, wie van der Laan zegt, zegt Talman, gelet op de volgorde van jullie namen in Engelstalige publicaties. We steken sinds 1992 met enige regelmaat onze drie hoofden bij elkaar in een gezamenlijke onderzoekssessie van één dag. Dit heeft inmiddels geleid tot een groot aantal gemeenschappelijke publicaties en de organisatie van het KNAW-colloquium in 1998. Deze onderzoekssessies verlopen steeds in een bijzonder prettige sfeer. De waarheid gebiedt hierbij wel te vermelden dat de ochtendsessie steevast aangewend wordt om alle bestuurlijk leed met een kwinkslag te verwerken. Ik ga ervan uit dat we hiermee, met inbegrip van de ochtendsessie, ook in de toekomst door zullen gaan.

\section{Hooggeleerde Drèze, hooggeleerde Polemanchakis, cher Jacques, cher Heracles,}

Je suis heureux d'avoir pu passer l'année académique 1995-1996 à Louvain-la-Neuve. L'esprit de recherche qui règne au CORE est extraordinaire. Il m'a donné la possibilité de me mettre à la hauteur des 
développements les plus récents dans le domaine de l'équilibre général, spécialement la théorie des marchés incomplets. Pendant cette année j'ail appris beaucoup de choses et j'apprends toujours de vous. C'est vous qui m'avez incité de passer une période prolongée aux Etats-Unis. Ce séjour à la Cowles Foundation de Yale University, lieu où a été fondé la base de la théorie de l'équilibre général dans les années cinquantes, a été une étappe inoubliable de ma vie. Vos qualités aussi bien scientifiques qu'humaines sont exemplaires.

Hooggeleerde Hens, zeergeleerde Schmedders, lieber Thorsten, lieber Karl,

Wir treffen uns regelmäBig und überall auf der Welt. Unsere Wege kreuzten sich unter anderem in Amsterdam, Berkeley, Berlin, Bielefeld, Braunschweig, Helvoirt, Istanbul, Kopenhagen, Louvain-la-Neuve, Maastricht, New Haven, Stanford, Tilburg, und Venedig. Es freut mich sehr, daß Ihr beide als Vortragende am Symposium zum Anlab meiner Inauguralrede teilgenommen habt. Ich habe während allen unseren Diskussionen ob morgens, mittags oder abends, auf angenehme Weise die Möglichkeit gehabt von Euch zu lernen. Ich hoffe und bin überzeugt, daß sich unsere Wege noch oft kreuzen werden.

Beste collega's van het departement Algemene Economie,

De afgelopen tien maanden heb ik als bijzonder enerverend en uitdagend, maar ook als plezierig en vertrouwd ervaren. Ik heb veel geleerd van het Maastrichtse onderwijssysteem. De manier waarop dit systeem geïmplementeerd is in de afstudeerrichtingen Algemene Economie, International Economic Studies en Infonomics, is een voorbeeld voor andere economische faculteiten. Ik wil jullie danken voor de prettige wijze waarop jullie mij in staat hebben gesteld een plaats in jullie midden in te nemen.

\section{Lieve Suzanne en Sander,}

Groot is mijn dank, Suzanne, voor het geduld en het begrip dat je weet op te brengen voor al die keren dat ik afwezig ben, op congres, op werkbezoek of in gedachten. Sander wil ik bedanken voor de gulle lach die hij me steevast schenkt als ik thuiskom. Samen vormen jullie het vaste punt in mijn leven. 
Zeer gewaardeerde toehoonders,

Na op tal van arbeidsmarkten te hebben rondgezworven, woel ik mij op die van de Universiteit Maastricht zeer thuis.

Ich höb gezag, of in het Nederlands, Ik heb gezegd. 


\section{Literatuur}

Arrow, K.J. (1951), An Exterision of the Basic Theorems of Classical Welfare Economics," Proceedings of the Second Berkeley Sympositum on Mathematical Statistice, in J. Neyman (ed.), University of Califormia Presis, Berkeley, pp. 507.532 .

Arrow, K.J. (1953), "te Rôle des Valeurs Bowrsieres pour la Répartition la Meilleure des Risques, in Econometrie, Colloques Internationaux du Centre National de la Recherce Scientifique, 40, 41-47; English version: "The Role of Securities in the Optimal Allocation of Risk-Bearing," Review of Economic Studies, 31, $91-96$.

Arrow, K.J., H.D. Block, en L. Hurwicz (1959), "On the Stability of the Competitive Equilibrium, 11," Econometrica, $27,82-109$.

Arrow, K.J., en G. Debreu (1954), "Existence of an Equilibrium for a Competitive Economy," Ecanometrica, 22, 265-290.

Arrow, K.J, en F.H. Hahn (1971), General Competitive Anolysis, Holden Day, San Francisco.

Arrow, K.J., en L. Hurwicz (1958), "On the Stability of the Competitive Equilibrium, 1," Econometrica, 26, $522-552$.

Benassy, J.-P. (1975), "Neo-Keynesian Disequilibrium Theory in a Monetary Economy", Revien of Economic Studies, 42, 503-523.

Blaug, M. (1980), The Methodology of Economics, Cambridge University Press, Cambridge.

Blaug, M. (1986), Great Economists before Keynes, An Introduction to the Lives and Works of One Hundred Great Economists of the Past, Edward Elgar, Brighton.

Böhm, V , en H. Müller (1977), "Two Examples of Equilibria under Price Rigidities and Quantity Rationing," Zeitschriff für Nationalökonomie, 37, 165-173.

Brouwer, L.E.J. (1912), "Über Abbildung von Mannigfaltigkeiten," Mothematische Annalen, 71, 97-115.

Browder, F.E. (1960), "On Continuity of Fixed Points under Defiormations of Continuous Mappings," Sumina Brasiliensis Mathematicae, 4, 183-191.

Brown, D.J "P.M. DeMarzo, en B.C. Eaves (1996), "Computing Equilibria when Asset. Markets Are Incomplete," Econometrica, 64, 1-27.

Brown, D.J., en R.L. Matzkin (1996), "Testable Restrictions on the Equilibrium Manifold, "Econometrica, 64, 1249-1262.

Dam., J. van, en A. Jolink (1993), The Equilibrium Economics of Leon Walras, Routledge, Lúndor.

Debreu, $G_{*}(1951)$, "The Coefficient of Resource Utilization," Econometrica, 19, $273-292$.

Debreu, Q. (1952), "A Social Equilibrium Existence Theorem," Proceedings of the National Academy of Sciences of the United States of America, 38, 886-893.

Debreu, G. (1959), Theary of Value, Yale University Press, New Haven. 
Debrew, G. (1970), "Economies with a Finite Set of Equilibra," Econometrica, ss; 387-392.

Debreu, G. (1974), "Excess Demand Functions", Jownal of Mathematical Economics, $1,15-21$.

Dierker, E. (1972), "Two Remarks on the Number of Equilibria of an Economy" Econometrica, 40,951-953.

Drèze, J.H. (1975), "Existence of an Exchange Equilbribum under Price Rijgiditivs," International Economic Review, 16, 301-320.

Drèze, J.H. (1997), Walras-Keynes Equilibria - Coordination and Macroeconomics, European Economic Review, 41, 1735-1762.

Drèze, J.H. (1999), "On the Macroeconomics of Uncertainty and Incomplete Markets," CORE Discussion Paper 9964, CORE, Louvain-la-Neuve, 1-29.

Drèze, J.H., en C. Gollier (1993), "Risk Sharing on the Labour Market" European Economic Review, $37,1457-1482$.

Drèze, J.H.n en H. Mülller (1980), "Optimality Properties of Rationing Schemes," Jowrnal of Economic Theory, 23, 131-149.

Duffie, D., en W. Shafer (1985), "Equilibrium in Incomplete Markets: I, A Basic Model of Generic Existence," Journal of Mathematical Econamics" 14, 285300.

Eaves, B.C. (1972), "Homotopies for Computation of Fixed Points," Mathematical Programming, $3,1-22$.

Edgeworth, F.Y. (1881), Mathematical Psychics, Kegan Paul, London.

Fama, E.F., en K.R. French (1992), "The Cross-Section of Expected Stock Returns," Journal of Finance, $47,427-465$.

Fisher, F.M. (1983), Disequilibrium Foundations of Equilibriun Economics, Cam bridge University Press, Cambridge.

Fisher, 1. (1925), Mathematical Investigations in the Theory of Value and Prices, Yale Uniwersity Press, New Haven.

Geanakoplos, J.D., en H.M. Polemarchakis (1986), "Existence, Regularity, and Constrained Suboptimality of Competitive Allocations when the Asset Market is Incomplete," in W.P. Heller, R.M. Starr, en D.A. Starrett (eds.), Uncetainty. Information and Communication: Essays in Honor of K.J. Arrow, Vol. IH, Cambridge University Press, Cambridge, pp. 65-96.

Geanakoplos, J.D., en M. Shubik 1990), whe Capital Asset Pricing Model as General Equilibrium with Incomplete Markets" The Geneva Papers on Risk and Insurance, $15,55-72$.

Grandmont, J.M. (1992), "Transfiomations of the Commodity Space Buhavioral Heterogeneity, and the Aggregation Problem," Journal of Economitic Theary, $57,1-35$.

Hahn, F.H, en T. Negishi (1962), "A Theorem on Non-tatonnement Stability," Econometrica, $30,463-469$.

Hart, O.D. (1975), "On the Optimality of Equilibrium when the Market Structure Is Incomplete," Journal of Economic Theary, in, 418-443. 
Hens, Th. (1995), General Equilirium Foundations of finance, Habilitation, 1 198.

Hens, Th. (1997), "Stability of Tatonnement Processes of Short Period Equilibria with Rational Expectations;" Journal of Mathematical Economics, 28, 41-67.

Hens, Th., K. Schmedders, B. Voss (1999), "On Mulliplicity of Competitive Equilibria when Financial Markets Are lnicomplete " in P.J.J. Herings, G. wan der Laan, en A.J. T. Thlman (eds.), The Theory of Markets, North-Holland, Amsterdam, $165-192$.

Herings, P.J.J. (1996a), "Equilibrium Existence Results for Economies with Price Rigiduties," Economic Theory, 7, 63-80.

Herings, P.J.J. (1996b), Static and Dynamic Aspects of General Disequalibritum Theory, Theory and Decision Library, Series C: Game Theory, Mathematical Programming and Operations Research, Kluwer Academic Publishers, Norm well, Massachusetts.

Herings, P.J.J. (1997a), "Endogenously Determined Price Rigidities," Economic Theory, $9,41-498$.

Herings, P.J.J. (1997b), A Globally and Universally Stable Price Adjustment Process," Journal of Mathematical Economics, 27, 163-193.

Herings, P.J.J. (1998), "On the Existence of a Continuum of Constrained Equilibriva, Joumal of Mathematical Economics, $30,257-273$.

Herings, P.J.J. (1999), "A Note on "Stability of Tatonnement Processes of Short. Period Equilibria with Rational Expectations"," Journal of Mathematical Eco. nomics, 32, 333-338.

Herings, P.J.J. (2000), "Universally Stable Adjustment Processes - a Unify"ing Approach," METEOR Research Memorandum 00/03, University of Maastricht, 1-29.

Herings, P.J.J., en J.H. Drèze (1998), "Continua of Underemployment Equilibria," CentER Discussion Paper 9805, CentER, Tilburg University, Tilburg, 1-32.

Herings, P.J.J., en A. Konovallov (2000), "Constrained Suboptimality in Competitive Models at Non-competitive Prices," in voorbereiding.

Herings, P.J.J., en F". Kubler (1999), "The Robustness of the CAPM - A Computational Approach," CentER. Discussion Paper 9954, CentER, Tilburg Univer: sity, Tilburg, 1-41.

Herings, P.J.J., G. van der Laan, A.J.J. Talman, en R. Venniker (1997), "Equilibrium Adjustment of Disequilibrium Prices, ${ }^{3}$ Joumal of Mathematical Economics, $27,53-77$.

Herimgs, P.J.J., G van der Latan, en R.J.G.Venmiker (1998), "The Transition from a Dreze Equilibrium to a Walrasian Equilibrium " Joumal of Mathematical Economics, 29, 303-330.

Herings, P.J.Ju, en H.M. Polemarchakis (1999), "Pareto Improwing Price Regulation when the Asset Market Is Incomplete," Cowles Foundation Discussion Paper No. 1210 , Yale Universilty New Haven, Connecticut, 1-42.

Herings, P.J.J. en K. Schmedders (2000), "Computing Equilibria in Finance Economies with Incomplete Markets and Transaction Cosits," in voorbereiding. 
Herings, P.J.J., en A.J.J. Talman (1998), "Intersection Theonems with a Continuum of Intersection Points," Journal of Optimization Theory and Applications, 96, 311-335.

Herings, P.J.J., A.J.J. Talman, en Z. Yang (1996), "The Computation of a Continuum of Constrained Equilibria," Mathematics of Operations Research, 21, 675-696.

Hildenbrand, W. (1983), "On the "Law of Demand"," Econometrica, 51, 997-1019.

Hildenbrand, W. (1989), "Facts and Ideas in Microeconomic Theory," European Economic Review, 33, 251-276.

Jongen, H.Th., P. Jonker, en F. Twilt (1983), Nonlinear Optimization in $\mathbb{R}^{n}, I$. Morse Theory, Chebyshev Approximation, Methoden und Verfahren der Mathematischen Physik, 29, Peter Lang, Frankfurt.

Jongen, H.Th., P. Jonker, en F. Twilt (1986), Nonlinear Optimization in $\mathbb{R}^{n}$, II. Transuersality, Flows, Porametric Aspects, Methoden und Verfahren der Mathematischen Physik, 32, Peter Lang, Frankfurt.

Kakutani, S. (194:1), "A Generalization of Brouwer's Fixed Point Theorem," Duke Mathematical Journal, 8, 457-459.

Kamiya, K. (1990), "A Globally Stable Price Adjustment Process," Econometrica, $58,1481-1485$.

Keenan, D.C. (1981), "Further Remarks on the Global Newton Method," Journal of Mathematical Economics, 8, 159-165.

Keynes, J.M. (1936), The General Theory of Employment, Interest and Money, MacMillan, London.

Kuhn, H.W., en J.G. MacKinnon (1975), "Sandwich Method for Finding Fixed Points," Journal of Optimization Theory and Applications, 17, 189-204.

Laan, G. van der (1982), "Simplicial Approximation of Unemployment Equilibria," Journal of Mathematical Economics, 9, 83-97.

Laan, G. van der, en A.J.J. Talman (1979), "A Restart Algorithm for Computing Fixed Points without an Extra Dimension," Mathematical Programming, 17, 74-84.

Laan, G. van der, en A.J.J. Talman (1987), "A Convergent Price Adjustment Process," Economics Letters, 29, 119-123.

Lakatos, I. (1970), "Falsification and the Methodology of Scientific Research Programmes," in I. Lakatos en A. Musgrave (eds.), Criticism and the Growth of Knowledge, Cambridge University Press, Cambridge, pp. 91-196.

Laroque, G., en H.M. Polemarchakis (1978), "On the Structure of the Set of Fixed Price Equilibria," Journal of Mathematical Economics, 5, 53-69.

Lintner, J. (1965), "The Valuation of Risky Assets and the Selection of Risky Investments in Stock Portfolios and Capital Budgets," Review of Economics and Statistics, 47, 13-37.

Magill, M., en M. Quinzii (1996), Theory of Incomplete Markets, MIT Press, Cambridge, Massachusetts. 
Mantel, R.R. (1974), "On the Characterization of Aggregate Excess Demand," Journal of Economic Theory, $7,348-353$.

Maskin, E.S., en J. Tirole (1984), "On the Efficiency of Fixed Price Equilibrium," Journal of Economic Theory, 32, 317-327.

McKenzie, L.W. (1954), "On Ecuilibrium in Graham's Model of World Trade and Other Competitive Systems, Econometrica, 22, $147-161$.

McKenzie, L.W. (1955), "Equality of Factor Prices in World Trade," Econometrica, $23,239-257$.

Neumann, J. von (1937), "Über ein ökonomisches Gleichungsisystem und eine Verallgemeinerung des Brouwerschen Fixpunktsatzes," Ergebnisse eines Mathematischen Kolloquiums, 8, 73-83.

Pareto, V. (1909), Manuel d'Économie Politique, Giard et Brière, Paris.

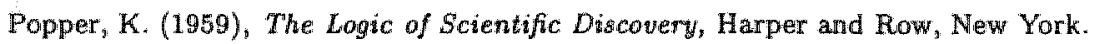

Popper $_{\text {K }}$ K. (1972), Conjectures and Refutations: The Growth of Scientific Knowledge, Routliedge, London.

Radner, R. (1972), "Existence of Equilibrium of Plans, Prices, and Price Expectations in a Sequence of Markets ${ }^{87}$ Econometrica, 40, 289-303.

Russell, B. (1931), The Scientific Outlook, Allen and Unwin, London.

Saari, D.G., en C.P. Simon (1978), "Effective Price Mechanisms," Econometrica, 46, $1097-1125$.

Samuelson, P.A. (1941), "The Stability of Equilibrium: Comparative Statics and Dynamics," Econometrica, 9, 97-120.

Scarf, H. (1960), "Some Examples of Global Instability of the Competitive Equilibrium," International Economic Review, 1, 157-172.

Scarf, H. (1967), "The Approximation of Fixed Points of a Continuous Mapping," SIAM Jourral on Applied Mathematics, 15, 1328-1343.

Scarf, H., en P.J.J. Herings (1998), "The Computation of Equilibrium Prices" in A. Kirman (ed.), Elements of General Equilibrium Analysis, Festschrift in Honor of Gerard Debreu, Blackwell Publishers, Oxford, pp. 132-138.

Schinkel, M.P., J. Tujustra, en D. Vermeulen (2000), "Bayesian Learning in Misspecified Models" METEOR Research Memorandum 00/08, University of Maastricht 1 1-66.

Sharpe, W.F. (1964), "Capital Asset Prices: A Theory of Market Equilibrium under Conditions of Risk," Journal of Finance, 19,425-442.

Silvestre, J. (1982), "Fixprice Analysis in Exchange Economies," Journal of Economic Theory, 26, 28-58.

Smale, S. (1976), "A Convergent Process of Price Adjustment and Global Newton Methods," Journal of Mathematical Economics, 3, 107-120.

Smith, A. (1776), An Inquiry into the Nature and Causes of the Wealth of Nations, W. Strahan and T. Cadell, London.

Sonnenschein, H. (1972), "Market Excess Demand Functions," Ecomometrica, 40, 549-563. 
Sonnenschein, H. (1973), "Do Walras' Identity and Continuity Characterize the Class of Community Excess Demand Functions?" Joumal of Economic Theory, $6,345-354$.

Uzawa, H. (1962), "On the Stability of Edgeworth's Barter Process," Intemational Economic Review, 3, 218-232.

Wald, A. (1936), "Über einige Gleỉchungssysteme der mathematischen Ökonomie," Zeitschrift für Nationalökonomie, $7,637-670$.

Wairas, L. (1874), Éléments d'Ëconomie Politique Pure, Corbaz, Lausanne, Switzerland.

Weintraub, E.R. (1985), Genenal Equilibrium Analysis, Studies in Appraisal, Cambridge University Press, Cambridge.

Younès, Y. (1975), "On the Role of Money in the Process of Exchange and the Existence of a Non-Walrasian Equilibrium," Review of Economic Studies, 48, 489-501. 